\title{
Main Structural Targets for Engineering Lipase Substrate Specificity
}

\author{
Samah Hashim Albayati ${ }^{1,2}$, Malihe Masomian ${ }^{3}$, Siti Nor Hasmah Ishak 1,2, \\ Mohd Shukuri bin Mohamad Ali 1,4,5, Adam Leow Thean 1,5,6 (D), \\ Fairolniza binti Mohd Shariff ${ }^{1,2}$, Noor Dina binti Muhd Noor ${ }^{1,4}$ and \\ Raja Noor Zaliha Raja Abd Rahman 1,2,5,*(D) \\ 1 Enzyme and Microbial Technology Research Centre, Faculty of Biotechnology and Bimolecular Science, \\ Universiti Putra Malaysia, Serdang 43400, Selangor, Malaysia; sama.hashim2019@gmail.com (S.H.A.); \\ snhasmahishak@gmail.com (S.N.H.I.); mshukuri@upm.edu.my (M.S.b.M.A.); \\ adamleow@upm.edu.my (A.L.T.); fairolniza@upm.edu.my (F.b.M.S.); dina@upm.edu.my (N.D.b.M.N.) \\ 2 Department of Microbiology, Faculty of Biotechnology and Bimolecular Science, Universiti Putra Malaysia, \\ Serdang 43400, Selangor, Malaysia \\ 3 Center for Virus and Vaccine Research, School of Science and Technology, Sunway University, \\ Kuala Lumpur 47500, Selangor, Malaysia; malihem@sunway.edu.my \\ 4 Department of Biochemistry, Faculty of Biotechnology and Bimolecular Science, Universiti Putra Malaysia, \\ Serdang 43400, Selangor, Malaysia \\ 5 Institute Bioscience, Universiti Putra Malaysia, Serdang 43400, Selangor, Malaysia \\ 6 Department of Cell and Molecular Biology, Faculty of Biotechnology and Bimolecular Science, \\ Universiti Putra Malaysia, Serdang 43400, Selangor, Malaysia \\ * Correspondence: rnzaliha@upm.edu.my; Tel.: +60-397691416
}

Received: 9 April 2020; Accepted: 5 May 2020; Published: 6 July 2020

\begin{abstract}
Microbial lipases represent one of the most important groups of biotechnological biocatalysts. However, the high-level production of lipases requires an understanding of the molecular mechanisms of gene expression, folding, and secretion processes. Stable, selective, and productive lipase is essential for modern chemical industries, as most lipases cannot work in different process conditions. However, the screening and isolation of a new lipase with desired and specific properties would be time consuming, and costly, so researchers typically modify an available lipase with a certain potential for minimizing cost. Improving enzyme properties is associated with altering the enzymatic structure by changing one or several amino acids in the protein sequence. This review detailed the main sources, classification, structural properties, and mutagenic approaches, such as rational design (site direct mutagenesis, iterative saturation mutagenesis) and direct evolution (error prone PCR, DNA shuffling), for achieving modification goals. Here, both techniques were reviewed, with different results for lipase engineering, with a particular focus on improving or changing lipase specificity. Changing the amino acid sequences of the binding pocket or lid region of the lipase led to remarkable enzyme substrate specificity and enantioselectivity improvement. Site-directed mutagenesis is one of the appropriate methods to alter the enzyme sequence, as compared to random mutagenesis, such as error-prone PCR. This contribution has summarized and evaluated several experimental studies on modifying the substrate specificity of lipases.
\end{abstract}

Keywords: lipase; specificity; binding pocket; lid; oxyanion hole; protein engineering; chemoselectivity; regioselectivity; stereoselectivity 


\section{Introduction}

The most widely used biocatalysts for oil and fat modification are lipases (EC 3.1.1.3, triglycerol hydrolases) [1]. Lipases have also been implemented in organic synthesis [2]. Eijkman discovered lipase over a century ago, and reported that many types of bacteria secreted and produced lipases, some of which could remain enzymatically active in organic solvents [3]. Lipases are very attractive, and ideal tools for organic chemistry due to many factors, such as their availability in large quantities, as many are produced by microbial organisms, including bacteria and fungi. Additionally, they display exquisite stereoselectivity, chemoselectivity, regioselectivity, and do not catalyze side reactions, or cofactors are necessitated. Many lipases crystal structures have been solved, facilitating the use of rational design strategies to improve their properties [4]. Lipases have been applied in numerous industries, such as pharmaceuticals, food, beverages, cosmetics, medical diagnostics, detergents, and papers. Furthermore, lipases have successfully been implemented in novel biotechnological applications, such as synthesis flavor, biodiesel, biopolymers, agrochemicals, and enantiopolymers pharmaceutical compounds [5]. However, certain applications require specific modifications of an enzyme's properties to meet the application requirements. This generally includes catalyst stereo-chemoselectivity, regioselectivity, activity at high substrate concentration, elevated temperature or extreme $\mathrm{pH}$. Molecular biology technology introduces two most essential strategies for modifying enzyme properties: direct evolution, which can be performed by random mutation, and rational design via site-directed mutagenesis [6]. To alter enzyme selectivity, many structural enzyme parts are used as the main target, such as altering the amino acid sequence by mutation in the active site-substrate binding area or lid region, which has been shown to mediate enzyme chain length selectivity [7].

\section{Primary Lipase Classification}

Different classes of carboxylic ester hydrolases enzymes (EC 3.1.1) are produced by microorganisms, and these are affiliated with the structural superfamily of $\alpha / \beta$-hydrolases, including lipases, esterases, and phospholipases. True lipases (EC 3.1.1.3) offer a high activity for hydrolyzing water-insoluble long, and medium-chain triglycerides, while esterases (EC 3.1.1.1) catalyze water-soluble short-chain triglycerides. Phospholipases share similarities of structure and catalytic mechanism with lipases and esterases, due to their substrate promiscuity, but they catalyze hydrolyzing phosphoglycerides ester bonds with an amphipathic nature, rather than neutral lipids [8-10]. Cutinases (E.C. 3.1.1.74), which belong to the $\alpha / \beta$-hydrolase superfamily originating from fungus, is another type of enzyme with characteristics similar to those of lipases and esterases. This enzyme catalyzes the hydrolysis of ester bonds in cutin polymers, and also catalyzes the hydrolyzing of long and short-chain triglyceride, without the requirement of interfacial activation [11]. For classifying the lipolytic enzyme as a "true" lipase (EC 3.1.1.3), two criteria should be available. Firstly, lipase activity should be increased when the triglyceride substrate forms an emulsion as interfacial activation. Secondly, the presence of the "lid" located on the protein surface covering the active site and opens when interfacial activation occurs [12]. Another criterion, which should be considered for discriminating lipase from esterase, is that lipase shows higher $\mathrm{K}_{\mathrm{m}}$ than esterase when hydrolyzing soluble esters, as well as the difference in their amino acid composition, and protein surface electrostatic distribution [13,14]. However, these criteria proved to be unsuitable for classification, due to some exception discovered in the last decades $[15,16]$.

\section{Advance Lipase Classification}

Novel thermophilic and psychrophilic microbial lipases have been recently isolated and overexpressed in heterologous host Escherichia coli. Unknown lipase producing species such as fungi, yeast, and bacteria have also been described and characterized according to their enantioselectivity toward carboxylic acids, alcohols, and other artificial substrates [17]. Based on biological properties and conserved sequence motifs, a lipase framework has been provided by Arpigny and Jaeger [18] classifying them into eight families. The "true" lipases of Gram-positive bacteria such as Staphylococcus, 
Bacillus, Propionibaceterium, Streptomyces, and lipases from the Gram-negative Pseudomonas are classified in Family I. Family I was formerly divided into 87 subfamilies sharing a consensus Gly-Xaa-Ser-Xaa-Gly (GXSXG) sequence [19]. Masomian et al. [20] reported a novel lipase from a thermophilic bacterium belonging to an uncharacterized subfamily of Family I. The new thermostable lipase represents subfamily I.9, which has properties between mesophilic and thermostable lipases. In Family, I, the subfamilies I.1, and I.2 lipases are dependent on their expression on a chaperone protein named lipase specific foldase (Lif).

These subfamilies have four conserved residues, namely two cysteines, which form a disulfide bridge, and two aspartic acids, implicated in the Ca-binding site. These conserved residues have been found to have homologous positions in all these subfamilies sequences. Furthermore, it has been suggested that their main role is in stabilizing enzymes' active sites [21]. Lipases produced by Bacillus and Geobacillus are generally grouped under subfamilies I.4 and I.5. In lipases from subfamily I.5, the first glycine is replaced by alanine residue in the conserved pentapeptide motif: Ala-Xaa-Ser-Xaa-Gly [18,22]. Lipases and esterases belong to Family II, exhibited a GDS (L) motif, which also consisted of the active-site serine residue. The lipolytic enzymes of this family do not demonstrate the conserved pentapeptide sequence (GXSXG), and the serine residue lies near the $\mathrm{N}$-terminal region of the protein [23]. These enzymes can modify their structures because of the flexibility of their active sites in the presence of specific substrates. This unique characteristic increased the enzyme substrate specificity range [24]. The hormone-sensitive lipases (HSL) have a high sequence similarity to mammalian HSL [25]. The HSL lipase catalyzed the hydrolysis reaction of triacylglycerols in adipose tissue [26]. The lipases of this family have two highly conserved consensus motifs, (HGG) GXSXG, and His-Gly-Gly. This motif plays an important role in the formation of the oxyanion hole [27]. The lipolytic enzymes classified in the Family V originated from psychrophilic, mesophilic, and thermophilic microorganisms. Ideally, this family has a common PTL, and conserved GXSXG motif [28]. Lipolytic enzymes of Family VI is well characterized, and classified according to their size. This family has the catalytic tried of Ser-Asp-His in their hydrolase fold, and esterase with molecular mass 23 to $26 \mathrm{kDa}$, represents the smallest enzyme of this family [21]. Esterases Family VII share the conserved GXSXG pentapeptide, and substantial amino acid sequence homology ( $40 \%$ similarity, $30 \%$ identity) [18]. The enzymes in Family VIII are similar to the $C \beta$-lactamases class, with the protein lengths of approximately 380 amino acids [29]. They are resistant to cephalothin, cefazolin, cefoxitin, and most penicillin, due to the presence of conserved ampC gene. They also code $\beta$-lactamase inhibitor- $\beta$-lactam combinations [30]. This trait relates to the $N$-terminal of class $\beta$-lactam, consisting of the conserved active site (Ser-Xaa-Xaa-Lys) [31]. The current classification of bacterial lipolytic enzymes is shown in Table 1.

\section{The Lipases Expression System}

Due to the availability of many prokaryotic expression system, such as bacteria and eukaryotic systems like mammalian cells, insects, filamentous fungi, and yeasts, production of lipases in a large quantity has been facilitated [32]. The isolation of the lipase coding genes is the primary step to express the protein [33]. Selecting the proper vector and host compatible with the gene sequence are the important parts of large-scale production of lipases. The commercial plasmids such as pGEM ${ }^{\circledR}$-T [34], pET 51 [35], pET-32 [20], and pTrcHis (A, B, C) plasmids [36], have broadly been used for cloning of isolated lipase genes. Among the bacteria are different strains of Gram-negative E. coli, which is widely used as a heterologous expression system. The availability of different commercial strain of E. coli with a wide range of molecular toolboxes, for instance, tags, vectors, and promoters, make it more suitable for building up an expression system for a correctly folded recombinant enzyme with a higher yield. However, many factors have confined the usage of this expression system, and much of this is related to the host bacterial inability to perform post-translational modifications, such as the correct formation of disulfide bridges, glycosylation, phosphorylation, and correct protein folding [37]. Around $52 \%$ of recombinant lipases are expressed in the E. coli expression system. The bacterial lipases that belong to 
the genera Burkholderia, Staphylococcus, Pseudomonas, Bacillus, Serratia, and a few lipases from the yeast genus Candida are generally used in the E. coli expression system [32]. The lipase produced by CALB has been expressed in E. coli and exploited as a biocatalyst in biodiesel production [38]. The prokaryotic organism, such as Gram-positive soil bacterium Bacillus subtilis, represent the second most used organism for expression recombinant protein after E. coli. This bacterium can secret protein directly to the media at high concentration, by fusing it with the N-terminal signal sequence [39].

On the other hand, the usage of yeasts and filamentous fungi, which represent the eukaryotic expression systems, is the choice to carry out post-translational modifications, as they have a sub-cellular organization system and they are preferred over bacterial expression hosts in food processing [32]. Saccharomyces cerevisiae is the first yeast used for the heterologous expression of recombinant proteins, as it can display high-molecular-weight proteins on its cell surface [40]. Another type of yeast which is considered a non-Saccharomyces yeast, Pichia pastoris, has been the most applied heterologous system for commercially protein production. However, the high level of expression and reduced hyperglycosylation are introduced by Pichia pastoris [41]. Around $34.6 \%$ of the recombinant lipases are expressed in P. pastoris [32]. Yan et al. [42] reported using P. pastoris as expression system for Thermomyces lanuginosus lipase gene cloned in to $\mathrm{pPICZ} \alpha \mathrm{A}$ plasmid. Among the filamentous fungi, Aspergillus species consider an attractive protein expression host, as it can produce and secrete a high amount of recombinant protein and can grow on an inexpensive medium [43]. Haegh et al. [44] used Aspergillus oryzae for expressing the Candida antarctica A and B lipase genes, cloned into pMT1229 and pMT 1335 plasmids, respectively. Aspergillus spp. and A. oryzae is the most expressive hosts used to express around $2.3 \%$ of all recombinant lipases [32].

Table 1. Current classification of bacterial lipolytic enzymes retrieved from UniProt database \& GenBank, [18,20,25,45-47].

\begin{tabular}{|c|c|c|c|}
\hline Family & Subfamily & Enzyme Producing Strain & $\begin{array}{c}\text { (Accession No, } \\
\text { UniProt or PDB) }\end{array}$ \\
\hline & 1 & $\begin{array}{c}\text { Family I } \\
\text { Pseudomonas aeruginosa (LipA) } \\
\text { Pseudomonas fluorescens C9 } \\
\text { Vibrio cholera } \\
\text { Pseudomonas aeruginosa (LipC) } \\
\text { Acinetobacter calcoaceticus } \\
\text { Pseudomonas fragi } \\
\text { Pseudomonas wisconsinensis } \\
\text { Proteus vulgaris } \\
\text { Rhodoferax ferrireducens } \\
\text { Vibrio harveyi } \\
\text { Vibrio parahaemolyticus } \\
\text { Aeromonas hydrophila } \\
\text { Dehalococcoides sp. VS } \\
\text { Proteus mirabilis } \\
\text { Chromobacterium violaceum }\end{array}$ & $\begin{array}{c}\text { D50587 } \\
\text { AF031226 } \\
\text { X16945 } \\
\text { U75975 } \\
\text { X80800 } \\
\text { X14033 } \\
\text { U88907 } \\
\text { U33845 } \\
\text { Q21T36 } \\
\text { A6AS17 } \\
\text { A6B1H2 } \\
\text { A0KFL9 } \\
\text { A8CY80 } \\
\text { 4GXN } \\
\text { Q7NU14 }\end{array}$ \\
\hline & 2 & $\begin{array}{c}\text { Burkholderia glumae } \\
\text { Burkholderia cepacia } \\
\text { Burkholderia multivorans } \\
\text { Burkholderia thailandensis } \\
\text { Pseudomonas KWI-56 } \\
\text { Pseudomonas luteola }\end{array}$ & $\begin{array}{c}\text { X70354 } \\
\text { M58494 } \\
\text { Q45VN4, A9AMF2 } \\
\text { Q2T7L1 } \\
\text { P25275 } \\
\text { AF050153 }\end{array}$ \\
\hline & 3 & $\begin{array}{c}\text { Pseudomonas fluorescens SIKW1 } \\
\text { Pseudomonas Fluorescens PfO1 } \\
\text { Pseudomonas sp. } 7323 \\
\text { Serratia proteamaculans } \\
\text { Serratia marcescens } \\
\text { Uncultured bacterium } \\
\text { Uncultured bacterium }\end{array}$ & $\begin{array}{c}\text { D11455 } \\
\text { Q3KCS9 } \\
\text { Q2KTB3 } \\
\text { A8GDX0 } \\
\text { D13253 } \\
\text { A7J993 } \\
\text { A0A0F7IH45 }\end{array}$ \\
\hline
\end{tabular}


Table 1. Cont.

\begin{tabular}{|c|c|c|c|}
\hline Family & Subfamily & Enzyme Producing Strain & $\begin{array}{l}\text { (Accession No, } \\
\text { UniProt or PDB) }\end{array}$ \\
\hline & \multirow{7}{*}{4} & Bacillus subtilis (LipA) & M74010 \\
\hline & & Bacillus amyloliquefaciens & A7Z124 \\
\hline & & Bacillus pumilus & A34992 \\
\hline & & Bacillus licheniformis & U35855 \\
\hline & & Bacillus megaterium & Q8RJP5 \\
\hline & & Bacillus clausii & Q5WDN0 \\
\hline & & Bacillus subtilis (LipB) & C69652 \\
\hline & \multirow{6}{*}{5} & Geobacillus stearothermophilus L1 & U78785 \\
\hline & & Geobacillus stearothermophilus P1 & AF237623 \\
\hline & & Geobacillus thermocatenulatus & X95309 \\
\hline & & Geobacillus thermoleovorans & AF134840 \\
\hline & & Geobacillus thermocatenulatus & $2 \mathrm{~W} 22$ \\
\hline & & Geobacillus zalihae & $2 \mathrm{DSN}$ \\
\hline & \multirow{7}{*}{6} & Staphylococcus aureus & M12715 \\
\hline & & Staphylococcus haemolyticus & AF096928 \\
\hline & & Staphylococcus epidermidis & AF090142 \\
\hline & & Staphylococcus hyicus & X02844 \\
\hline & & Staphylococcus xylosus & AF208229 \\
\hline & & Staphylococcus warneri & AF208033 \\
\hline & & Staphylococcus simulans & Q84EK3 \\
\hline & \multirow{3}{*}{7} & Propionibacterium acnes & X99255 \\
\hline & & Streptomyces cinnamoneus & U80063 \\
\hline & & Corynebacterium glutamicum & Q8NU59, Q8NU60 \\
\hline & \multirow{7}{*}{8} & Fervidobacterium Rt17-B1 & ABS61180 \\
\hline & & Thrmosipho melanesiensis B1429 & ABR31744 \\
\hline & & Thermotoga petrophila RKU-1 & WP011943454 \\
\hline & & Thermotoga maritima MSB8 & WP 004082539 \\
\hline & & Thermotoga sp RQ & WP012310808 \\
\hline & & Pseudoalteromonas haloplanktis & Q3IF07 \\
\hline & & Pseudoalteromonas tunicata & A4CF12 \\
\hline & \multirow{14}{*}{9} & Aneurinibacillus thermoaerophilus strain $\mathrm{HZ}$ * & GU272057 \\
\hline & & Bacillus pseudomycoides DSM 12442 & WP_006094994 \\
\hline & & Bacillus mycoides Rock3-17 & EEM11082 \\
\hline & & Bacillus cereus B4264 & WP 000517067 \\
\hline & & Bacillus anthracis str. CDC684 & ACP13431 \\
\hline & & EML $1 *$ & DQ229155 \\
\hline & & Lip $G^{*}$ & DQ458963 \\
\hline & & Lip EH $166^{*}$ & EU515239 \\
\hline \multicolumn{3}{|r|}{ Family II } & \\
\hline & & Salmonella typhimurium & AF047014 \\
\hline & & Photorhabdus luminescens & X66379 \\
\hline & & Pseudomonas aeruginosa & AF005091 \\
\hline & & Pseudomonas putida & Q0P6P2,Q6B6R8, \\
\hline & & Xanthomonas vesicatoria & Q7X4K7 \\
\hline \multicolumn{4}{|c|}{ Family III } \\
\hline & & Streptomyces exfoliates & M86351 \\
\hline & & Kineococcus radiotolerans & A6WEQ4 \\
\hline & & Moraxella sp & X53053 \\
\hline & & Clavibacter michiganensis & B0RCM8, B0RFW0 \\
\hline & & Streptomyces albus & U03114 \\
\hline & & Thermobifida fusca & Q47RJ6, Q47RJ7 \\
\hline \multicolumn{4}{|c|}{ Family IV } \\
\hline & & Escherichia coli & AE000153 \\
\hline & & Archaeoglobus fulgidus & AE000985 \\
\hline & & Pseudomonas sp. B11-1 & (AF034088) \\
\hline & & Alcaligenes eutrophus & L36817 \\
\hline
\end{tabular}


Table 1. Cont.

\begin{tabular}{|c|c|c|c|}
\hline Family & Subfamily & Enzyme Producing Strain & $\begin{array}{l}\text { (Accession No, } \\
\text { UniProt or PDB) }\end{array}$ \\
\hline \multicolumn{4}{|c|}{ Family V } \\
\hline & & Sulfolobus acidocaldarius & AF071233 \\
\hline & & Haemophilus influenza & U32704 \\
\hline & & Moraxella sp & X53869 \\
\hline & & Psychrobacter immobilis & X67712 \\
\hline & & $\begin{array}{c}\text { Polaromonas naphthalenivorans } \\
\text { EstF ** }\end{array}$ & A1VLL6 \\
\hline \multicolumn{4}{|c|}{ Family VI } \\
\hline & & Spirulina platensis & Q53415 \\
\hline & & Anabaena variabilis & Q3M6G8 \\
\hline & & Bordetella avium & Q2KUZ2 \\
\hline & & Polaromonas sp. JS666 & Q127I1 \\
\hline & & Shewanella amazonensis & A1S771 \\
\hline & & Xanthomonas campestris & B0RNI6, Q3BXV6 \\
\hline & & Rhodoferax ferrireducens & Q21XU9 \\
\hline \multicolumn{4}{|c|}{ Family VII } \\
\hline & & Streptomyces coelicolor & Q9Z545 \\
\hline & & Bacillus pumilus & Q66M67 \\
\hline & & Bacillus stearothermophilus & Q8GCC7 \\
\hline & & Bacillus subtilis & P37967 \\
\hline & & Arthrobacter oxydans & Q01470 \\
\hline \multicolumn{4}{|c|}{ Family VIII } \\
\hline & & Pseudomonas fluorescens SIKW1 & AAC60471 \\
\hline & & Streptomyces chrysomallus & CAA78842 \\
\hline & & Arthrobacter globiformis & AAA99492 \\
\hline & & Arthrobacter aurescens & A1RB78 \\
\hline & & Saccharopolyspora erythraea & A4F8E6 \\
\hline & & Pseudomonas gingeri & B0M0H4 \\
\hline & & Pseudomonas syringae & Q48LQ9 \\
\hline
\end{tabular}

Note: The bacterial lipolytic families I-VIII, described in the Arpigny and Jaeger classification. The new lipases discovered by functional metagenomics indicated by an asterisk $\left(^{*}\right)$ originated from marine metagenome, and the lipases indicated by $(* *)$ are originated from marine sediments and adapted from [18,20,25,45-47].

\section{Lipases Main Structural Features}

\subsection{The Lid}

The presence of a lid is one of the required criteria for the "true lipase" classification [12,48]. This mobile subdomain is amphipathic structures, as their hydrophilic side faces the solvent in the closed conformation, while directing his hydrophobic side toward the catalytic active site [49]. The lid or (flap) structure, which is variable in length, is constituted of one or more $\alpha$ helices with two hinge segments on both ends. This structure is functionally essential, because it is responsible for exposing the hydrophobic trench in the presence of a substrate [50]. When the flap or lid is closed the lipase is inactive, as the lid protects the active site from substrate accessibility. In open conformation, substrates can be entered, and accommodated in the active sites to be converted to a product [51]. In aqueous media, lipase usually reveal very low catalytic activity, which may be related to the "closed" conformation assumed under these conditions. However, in the state of an aqueous-organic-interphase or organic media (hydrophobic), the lipase reveals higher activity, which may be related to an open conformation. The higher activity of lipases in polar-aqueous interphases media is known as "interfacial activation" [52]. The movement of the lid domain, which is covering the active site achieved by rotating around two hinge regions at the lipid-water interface condition, this movement creates a large hydrophobic trench around the active site, resulting in lipase activation [53]. However, for lipase activation, the presence of a sufficient interface is always necessary, more than the entity of substrate or its analog or inhibitor. This is called the molecular (bio)-imprinting property [54]. Other factors 
may also affect the lipase specificity, and their activity, such as the physicochemical state of the lipid substrate, Interfacial quality, and surface pressure are examples of physiochemical lipid substrate states, which are affected by lipase adsorption to lipid particles [55]. Previous studies have shown that mutations in the hinge region or on the lid affect the enzyme chain length selectivity (substrate), and the enzyme thermostability [56]. Lipase can be classified into three groups on the base of the type of lid domain. The first lipases are those without lids, such as Bacillus subtilis lipase (PDB: 1I6W) [57], followed by lipases with one loop or helical lid such as Burkholderia cepacia lipase (PDB: 3LIP) [58], and lipases with multiple helical lid, such as Candida antarctica lipase (PDB:2VEO) [59]. The different types of lipase's lids are shown in Figure 1.

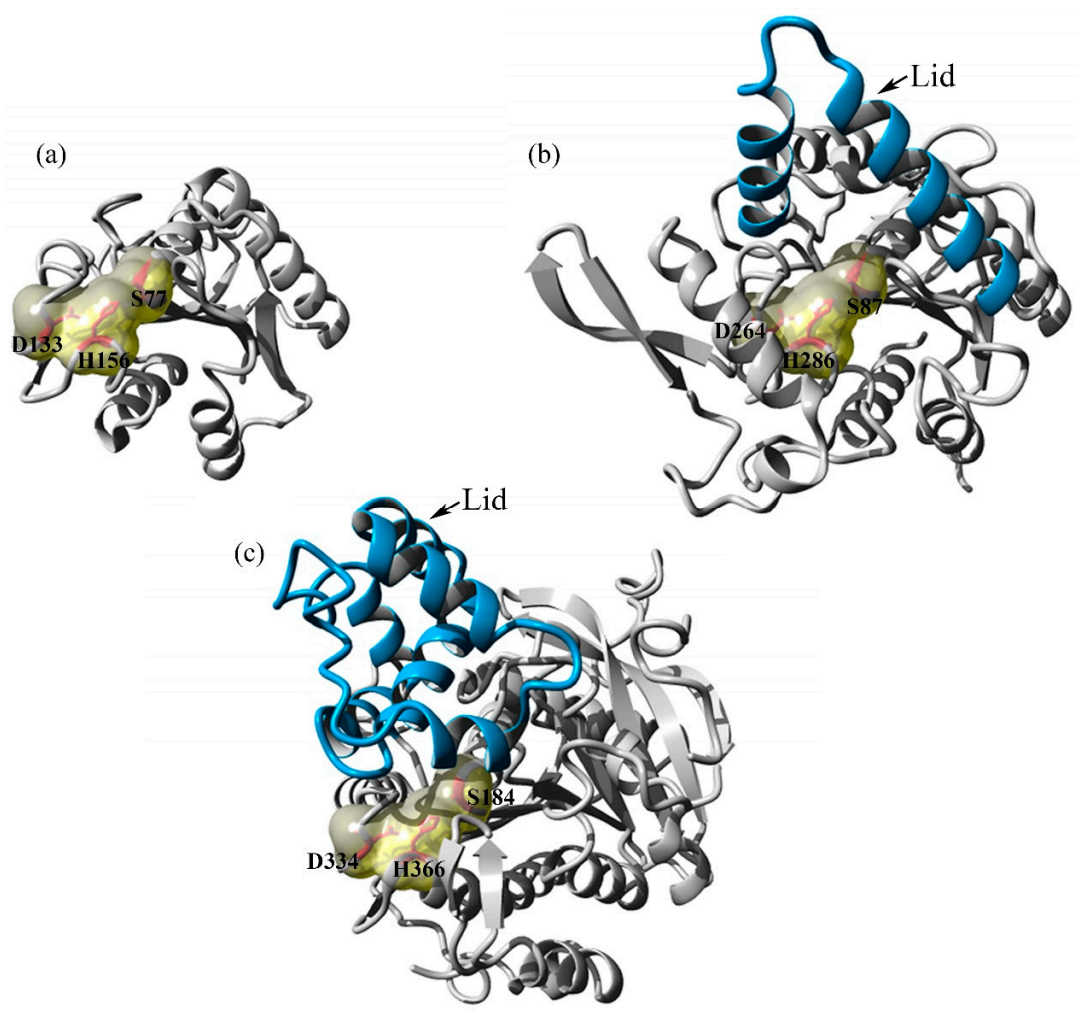

Figure 1. Three types of lipase's lids with the position of catalytic triads residues shown. (a) Bacillus subtilis lipase, with no lid domain (PDB: 1I6W) [57]; (b) Burkholderia cepacia lipase, with a loop of the lid (PDB: 3LIP) [58]; (c) Candida antarctica A lipase, with multiple helices of the lid (PDB: 2VEO) [59]. Catalytic triad residues were highlighted by red residues and yellow surface and lid domains were highlighted by blue color. (Figures prepared by http://www.yasara.org).

\subsection{The Oxyanion Hole}

An oxyanion hole is a basic structure typically found in many enzyme structures. They are crucial for high-energy oxyanion intermediate stabilization, through hydrogen bonding between their amide proton, and the substrate oxygen carbonyl group. When hydrolysis starts, a negatively charged tetrahedral intermediate is produced, and stabilizes the formed oxygen ion by hydrogen bonds, which are created by the oxyanion hole [60-62]. The website Lipase Engineering Database (LED) (http://www.led.uni-stuttgart.de) integrates microbial lipase, esterase for 112 homologous families and information on 38 superfamilies for sequence, structure, and function $[62,63]$. In lipases which are structurally conserved with a nucleophilic elbow, the first oxyanion hole residue of the consensus sequence G-X1-S-X2-G is the X2 residue, located next to the catalytic serine after strand $\beta 5$, whereas the second oxyanion hole residue is located in the loop between the $\beta 3$-strand, and the $\alpha \mathrm{A}$-helix at the $\mathrm{N}$-terminal part [60]. Lipases are classified into three classes according to their oxyanion hole type: (i) GX, (ii) GGGX, and (iii) Y. In the GX type, G is a conserved glycine, and X is either hydrophobic or 
hydrophilic oxyanion hole residue. The lipase with GX oxyanion hole usually prefers hydrolyzing medium, and long carbon chain length substrates. In the GGGX type, the oxyanion hole residue G is followed by a conserved hydrophobic residue, and this type is found to prefer short length carbon chain substrate [62,64]. The Y-type oxyanion hole is formed by the hydroxyl group of tyrosine side chain. This type is found in C. antarctica A lipase, some esterase, and a few bacterial lipases [65]. The different types of oxyanion holes are shown in Figure 2.

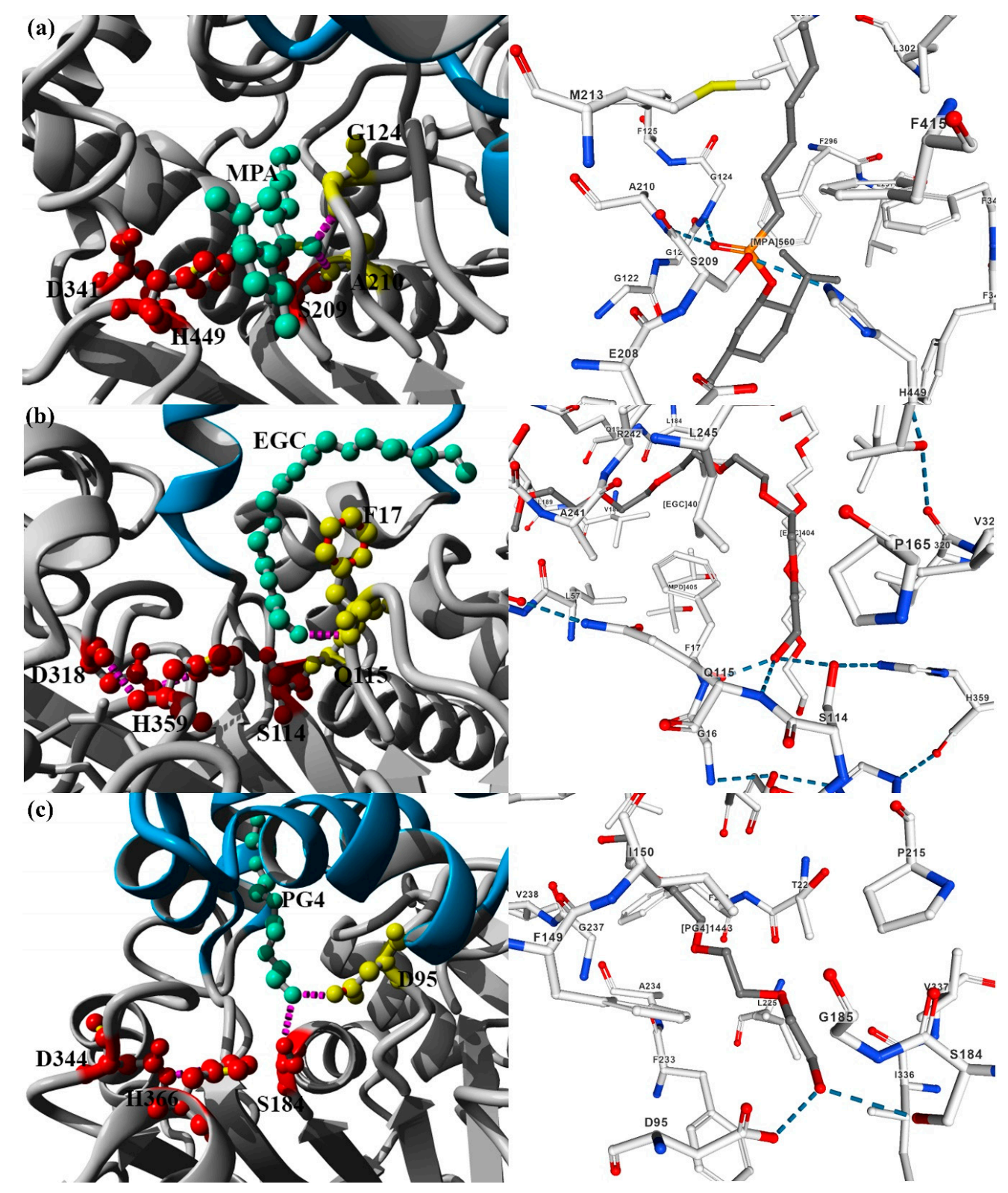

Figure 2. Three types of oxyanion holes. (a) GGG X type in Candida rugosa PDB (1LPM): (1R)- Menthyl hexyl phosphonate (MPA), inside binding area stabilized by hydrogen bonds of two oxyanion hole residues Ala 210 and Gly 124 [66]. (b) GX type in Geobacillus thermocatenulatus lipase (PDB 2w22): Triton X-100 (EGC), stabilized by hydrogen bonds of two oxyanion hole residues Phe 17 and Gln 115 [67]. (c) Y type in Candida antarctica lipase PDB (2VEO): (PG4) Polyethylene glycol stabilized by hydrogen bonds of one oxyanion hole residue Asp 95 [59]. Magenta dotted lines represent hydrogen bonds, green color molecules represent the substrates, red color residues are the active sites residues and yellow residues represent the oxyanion hole residues. (Figures prepared by http://www.yasara.org) [68]. The cartoon representation was rendered with an NGL viewer (generated from www.rcsb.org) [69]. 


\subsection{Substrate Binding Area}

The position of the binding site in all serine esterases and lipases are located inside a pocket on top of the central $\beta$ sheet. In lipases, the border of the pocket at the protein surface is hydrophobic, and is assumed to interact with the hydrophobic substrate interface. The hydrophobic interaction area of the substrate binding pocket in esterase and lipases is different in size, shape, deepness, and physio-chemical properties. According to the shape of the binding site pocket, lipases can be subdivided into three categories: (1) lipases with a funnel-like binding site (lipases from the mammalian pancreas, and cutinase), Pseudomonas sp. and Candida antarctica B; (2) lipases with tunnel-like binding sites, Candida rugosa, and Candida antarctica A; (3) lipases with a crevice-like binding site near the protein surface, Rhizomucor sp. and Rhizopus sp. [7,70,71]. The shapes of five types of the binding site of lipases identified by Pleiss \& Fischer [7] are shown in Figure 3. The shape of the acyl binding site reflects the substrate specificity. Lipases have a hydrophobic long scissile fatty acid binding site positioned inside the binding pocket at the wall of a binding funnel or in a crevice or a tunnel. While esterases have a small acyl binding pocket, which fits their substrate. Reducing the size of its acyl binding site would result in substrate steric conflicts. On the other hand, increasing the size of the acyl binding site would create free space, resulting in a sub-optimal binding of the substrate, and decreasing the $\mathrm{K}_{\mathrm{cat}} / \mathrm{K}_{\mathrm{m}}$ [7] will also limit the orientation of chiral substitutes by providing insufficient steric exclusion effects [72]. Many studies showed that substituting amino acids in the entrance of enzyme active sites changed the enzyme substrate selectivity [73]. Gosh et al. [74] changed the CRL enzyme specificity from triglycerides to cholesteryl esters by replacing Ser 450 in CRL1 to Ala in CRL3 located in the substrate binding area, as this residue prevents the direct steric conflict, to accommodate the hydrophobic cholesteryl moiety in the hydrophobic cleft. Quaglia et al. [75] identified the hot spot for engineering Candida antarctica A lipase for triglyceride chain length selectivity, located on the substrate binding area next to catalytic serine. The residue Tyr183F is essential for discriminating short-chain triglycerides. Another study showed that exposing the bacterial cocaine esterase, cocE, as hydrolyzing cocaine to mutation at Q55E in the active site resulted in a modest (2-fold) improvement in $\mathrm{K}_{\mathrm{m}}$, but a 14-fold loss of $\mathrm{K}_{\text {cat }}[76]$.

\subsection{Enzyme Catalytic Mechanism}

The enzyme catalytic mechanism starts when the catalytic serine oxygen atom attacks the carbonyl group carbon atom of the ester linkage. Subsequently, substrate hydrolysis starts, and generates a tetrahedral intermediate that creates hydrogen bonds with nitrogen atoms backbone in the "oxyanion hole." This oxyanion hole hydrogen bond stabilizes the negatively charged transition state that occurs during hydrolysis. After releasing alcohol, the acyl-lipase complex is subsequently hydrolyzed, producing free fatty acid, and regenerating the enzyme [77-80]. The electrostatic surface of many lipase and esterases have been mapped in their optimum ( $\mathrm{pH}$ 6-10) range, and these mapping results have shown that the active sites are negatively charged. According to the "electrostatic catapult" mechanism, the ionized carboxylic acid is immediately expelled from the active site after the ester cleavage, due to the electrostatic repulsion between the active site's negative electrostatic and the negatively charged carboxyl group [81]. 

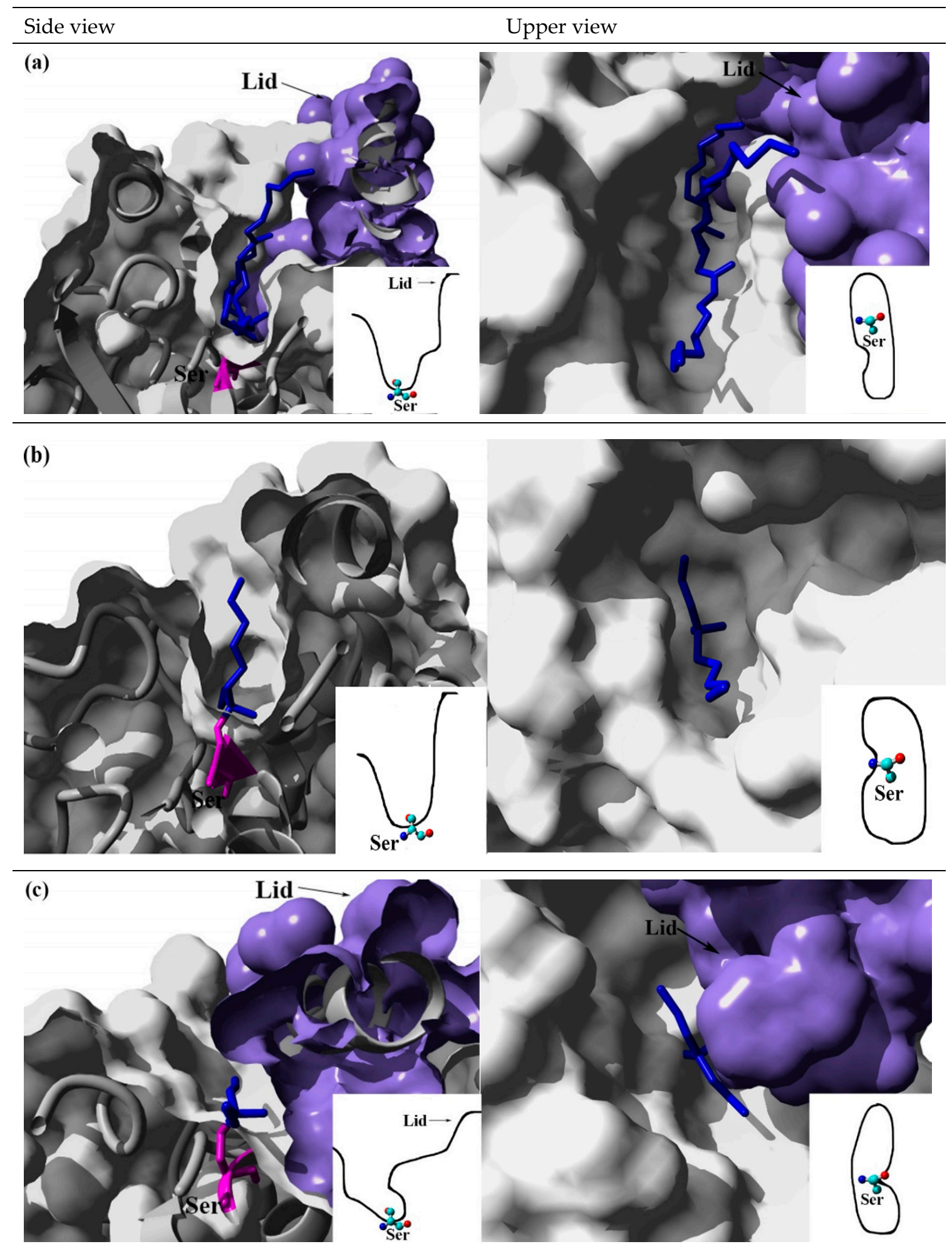

Figure 3. Cont. 

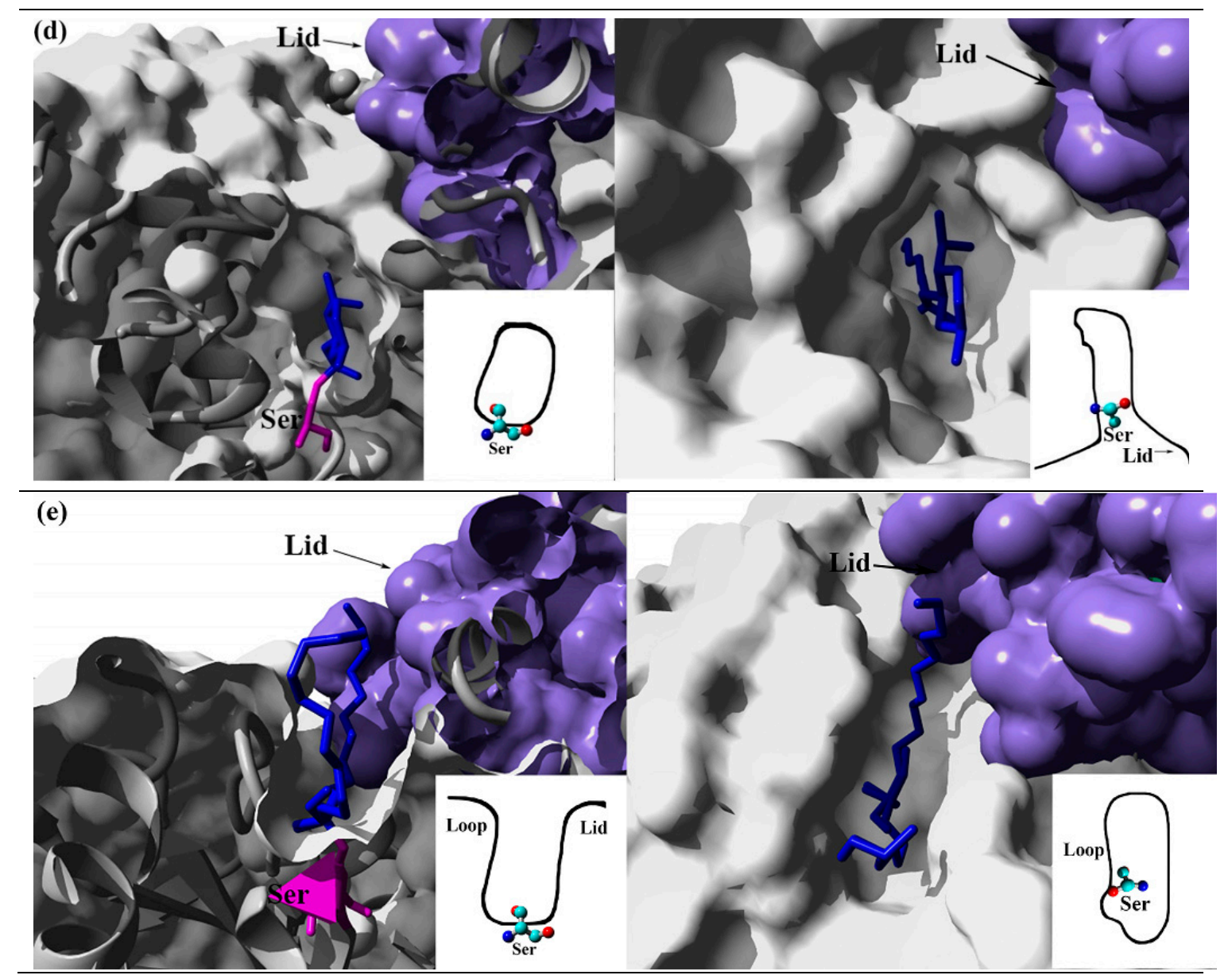

Figure 3. Shapes of the five types of binding sites of lipases as identified by Pleiss \& Fischer [7]. (a) Pseudomonas aeruginosa PAO1 (PDB: 1EX9) [82]. (b) Candida antarctica lipase B (PDB: 1LBS) [83]. (c) Rhizomucor miehei lipase (PDB: 4TGL) [84]. (d) Candida rugosa lipase (PDB: 1LPM) [66]. (e) Human pancreatic lipase (PDB: 1LPB) [85]. The purple surface represents the lid structure. The residue color in magenta represents the catalytic Ser. The residue color in blue represents the substrate. (Figures prepared by http://www.yasara.org).

\section{Lipase Selectivity}

Lipase can also be classified according to their substrate specificities. In this classification strategy, the enzymes are grouped on the base of their ability to discriminate between different substrates. There is a definite relationship between enzyme catalysis, selectivity/specificity, and many theories were put forward to explain enzyme catalysis, which includes enzyme-transition state stabilization [86], enzyme-transition state complementarity [87], and electrostatics [88]. Enzymes specificity and selectivity for catalyzing different substrates can be determined by the complementary between the substrate and the enzyme, as well the particular interactions between the substrate and enzyme residues. The selective value, between two substrates 1 and 2, is expressed by the ratio of constant specificity of the two substrates $\left(\mathrm{K}_{\mathrm{cat}} / \mathrm{K}_{\mathrm{m}}\right) 1, /\left(\mathrm{K}_{\mathrm{cat}} / \mathrm{K}_{\mathrm{m}}\right) 2$ [86]. However, the preference for a different substrate is associated with selectivity type, e.g., mono-di-triglycerides. $\mathrm{Xu}$ et al. [89] have reported the selectivity of Malassezia globose Lip 1 as it is inactive on triacylglycerols, and highly selective for mono and diglycerides. Furthermore, the selectivity for different fatty acid chain lengths such as short, medium, or long-chain fatty acids, and the degree of unsaturation is also a selectivity type. The shape of the enzyme binding site and the nature of the amino acids (sequences) forming the binding site is the main key controlling lipase preference for different sizes of acyl groups. In addition, the homologous isoforms of C. rugosa lipase vary in their specificity of the fatty acids chain length, 
due to differences in their tunnel-shaped binding site as differing in their amino acids [90]. There are varying types of substrate selectivity such as chemoselectivity, regioselectivity, and stereoselectivity that are reviewed in detail.

\subsection{Chemoselectivity}

The ability for enzymes to differentiate between substrates with different chemical groups is known as chemoselectivity, as demonstrated by Candida Antarctica lipase (CALB). The CALB lipase has 105 times higher selectivity for alcohol groups compared to the thiol groups [91]. Lipase chemoselectivity has been implemented in the polymer end group functionalization for building further branched and cross-linked complicated polymers architecture and structure [92]. Figure 4 shows lipase catalyzed chemoselective macrocyclic lactone 2-methylene-4-oxa-12-dodecanolide polymerization to produce polyester, having the exo-methylene group in the main chain, as no further methylene group proceeding reaction [93]. Whereas using anionic vinyl for polymerization will form an undesired gel after $1 \mathrm{~h}$, because of the cross-link reaction. Lipase chemoselectivity is commonly used in macrocylic lactones polymerization with unsaturated or epoxyl groups (ambrettolide epoxide, ambrettolide globalide) to produce an unreacted functional group with aliphatic polyester [94-96]. Hence, Lipase catalyze 5-allyloxy-1,3-dioxan-2-one, will result in polymerization when methoxy poly (ethylene glycol) is used as an initiator. This reaction will result in an amphiphilic copolymer containing pendent $-\mathrm{CH}=\mathrm{CH} 2$ group, which was then modified by mercaptan acid through the thiol-ene "click" reaction. The modified copolymer will facilitate the doxorubicin loading and delivery via the synergistic hydrophobic and electrostatic interactions. In addition, the resulted nanoparticles were efficiently implemented to realize the effective cellular uptake and potent cytotoxic activity against cancer cells [97,98]. A chemoselectivity characteristic can also be exploited in biodiesel and high purity diacylglycerols production $[99,100]$.
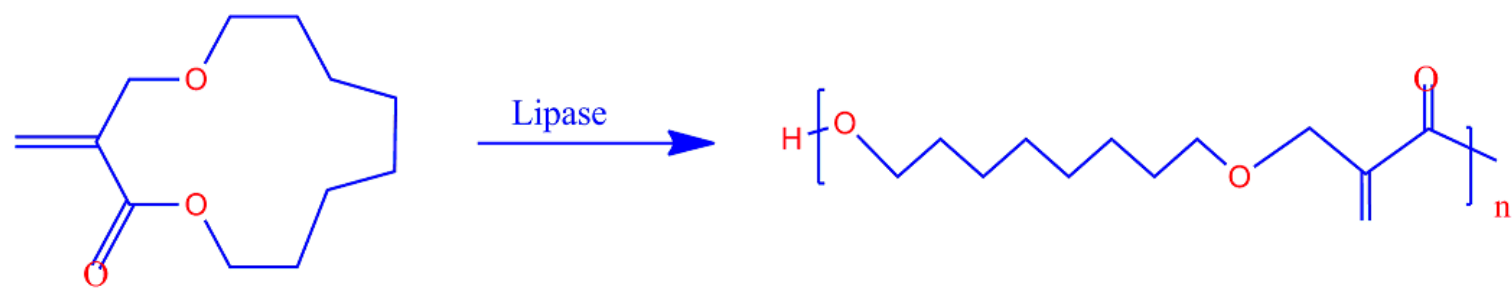

Figure 4. Lipase-catalyzed chemoselective macrocyclic monomer 2-methylene-4-oxa-12-dodecanolide polymerization [93].

\subsection{Regioselectivity}

The origin of the regioselectivity has been studied widely [101,102]. Quantum mechanics $(\mathrm{QM})$, and hybrid quantum mechanics/molecular mechanics (QM/MM) are the typical computational methods used to compare and compete for reaction barriers, which result in different products [103,104]. The regioselectivity for an enzyme is determined when the substrate binds to the enzyme active site, and the enzyme starts catalyzing the chemical reaction [105]. Achieving a complete understanding of enzyme regioselectivity is quite complicated, as a specific substrate can exhibit quite different regioselectivity with different members in one enzyme family. Regioselectivity represents an enzyme's ability to be selective for one of two similar chemical groups on the same substrate molecules, such as hexokinases that catalyzes the phosphorylation of glucose producing glucose-6-phosphate, but no other type of glucose phosphate (glucose-1phosphate or glucose-3-phosphate) [106]. Lipase regioselectivity also identifies as the ability to steer the reaction in the preferential direction over the other reaction's side. The reactions catalyzed by non-specific and specific $(1,3),(2)$ lipases are shown in Figure 5. This property is exploited in pharmaceutical and chemical industries, such as in isomeric compound productions to reach optimal functions under specific configuration. Recently findings, that lipase originated from Rhizopus oryzae displayed regioselective acylation of quercetin with ferulic acid. This property implemented efficiently to synthesize flavonoid derivatives [107]. In the deprotection 
process of per-O-acetylated thymidine, Candida rugosa lipase regioselectivity is used in producing $3^{\prime}-\mathrm{OH}-5^{\prime}-\mathrm{OAc}$-thymidine, as shown in Figure 6 [108]. The lipase regioselectivity can be further classified according to their catalyzing selectivity, as stated in Table 2.

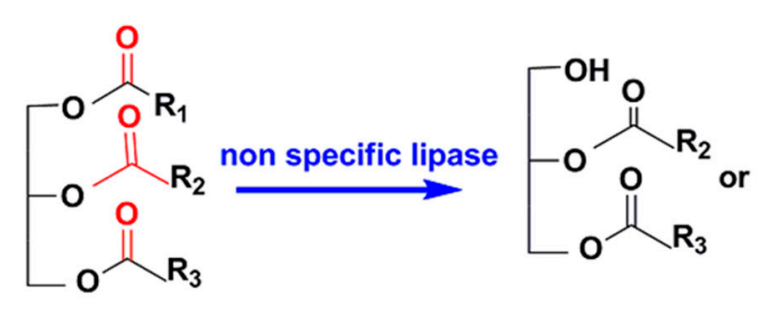<smiles>[R]C(=O)OCC(CO)OC([R2])=O</smiles><smiles></smiles><smiles>[R]C(=O)OCC(CO)OC([R2])[R]</smiles><smiles></smiles>

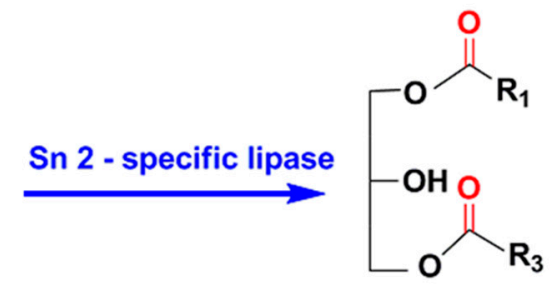

Figure 5. Reactions catalyzed by non-specific and 1,3 specific lipases [109].<smiles></smiles>

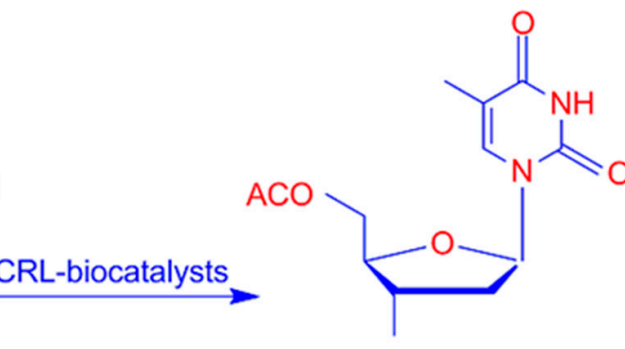

$\mathrm{OH}$<smiles></smiles>

3

Figure 6. Candida rugosa (CRL) lipase, catalyze regioselective deprotection of 3,5-O- diacetylated thymidine 1 with different aldehyde [108].

\subsection{Stereoselectivity}

Enzyme selectivity toward specific stereoisomer substrate (chiral molecule), means the enzyme reacts with one of the isomers faster than the others, for example, D-amino acid oxidase displays high enantioselectivity for oxidation D-amino acid substrate, while there is no activity toward the 
L-amino acid substrate [110]. The ability of lipases to determine the chiral structure of secondary alcohol enantiomers depends on the Kazlauskas rule, by which the enantiomers discrimination requires matching between the size of the corresponding binding pockets, and the size of the substituents at the stereocenter [111]. Recently, many factors related to the discrimination of enantiomers or diastereomers have been identified with the development of protein crystallography and computational simulation technologies, which mainly depends on the steric hindrance related to Kazlauskas rule structural rules. These factors depend on the complementarity between the substrate, and the topological structure of a lipase active site [112]; the hydrogen bonds between the tetrahedral intermediates, and the catalytic site surrounding residues [72]; the flexibility of structural region [113]; and the enzyme surface residue electrostatic interactions [89]. The stereoselectivity of lipase is well implemented in the pharmaceutical and agrochemical industries, as it is used in the production of single enantiomers, instead of racemic mixtures because, in most cases, only one of the two enantiomers has the desired activity, whereas the others enantiomers have no activity or even produce undesirable side effects [114]. Lipase enantioselectivity has also been used for pharmaceutical product production processes by transesterification of secondary alcohols [115].

Table 2. Classification of microbial lipase according to their $s n$ regioselectivity.

\begin{tabular}{lcc}
\hline \multicolumn{1}{c}{ Bacterial Species } & Sn- Regioselectivity & References \\
\hline Chromobacterium viscosum & Non-specific & {$[116]$} \\
Pseudomonas glumae & Non-specific & {$[116]$} \\
Rhizopus delemar & 1,3 & {$[117]$} \\
Rhizomucor miehei & 1,3 & {$[117]$} \\
Rhizopus oryzae & 1,3 & {$[117]$} \\
Fusarium heterosporum & 1,3 & {$[117]$} \\
Staphylococcus & 2 & {$[118]$} \\
Psudozyma tsukubaensis & Non-specific & {$[119]$} \\
Candida rugosa & Non-specific & {$[90,119]$} \\
Geotricum candidum I, II & Non-specific & {$[119,120]$} \\
Geotrichum candidum III & 2 & {$[120,121]$} \\
Staphylococcus aureus & Non-specific & {$[122]$} \\
Rhizomucor endophyticus & 1,3 & {$[123]$} \\
Rhizopus niveus & 1,3 & {$[100]$} \\
Candida humicola & 1,3 & {$[124]$} \\
Candida foliorum & 1,3 & {$[124]$} \\
Candida auricularia & 1,3 & {$[124]$} \\
Candida antarctica B & 1,3 & {$[125]$} \\
Malbranchea cinnamomea & 1,3 & {$[126]$} \\
Aspergillus niger & 1,3 & {$[116]$} \\
Thermomyces lanuginosus & 1,3 & {$[127]$} \\
Yarrowia lipolytica & 1,3 & {$[128]$} \\
Penicillium expansum & Non-specific & {$[129]$} \\
Burkholderia cepacia & Non-specific & {$[130]$} \\
Pseudomonas fluorescens & Non-specific & {$[116]$} \\
Pseudomonas aeruginosa sp & Non-specific & {$[130]$} \\
\hline & &
\end{tabular}

\section{Lipase Reactions and Applications}

Many industrial processes for producing different products such as biodiesel, flavors, food, and cosmetics, are mediated by the catalyzing lipases. However, in an industrial application, the thermal stability is the most desirable feature of an enzyme, which is employed in processes that require temperatures greater than or equal to $60^{\circ} \mathrm{C}$, as the majority of industrial lipolytic reactions run in high temperatures. Lipases are most preferred if they are thermostable. This is because of the high temperatures employed in an industrial lipolytic reaction [131]. Thermostable lipases have been isolated from extreme thermophilic, thermophilic, and mesophilic bacteria, such as from Pseudomonas sp, Bacillus sp. Geobacillus zalihae, and Thermoanaerobacter thermohydrosulfuricus, which were widely 
studied $[22,132,133]$. Similar to their counterpart, the cold-adapted lipases have also been adapted in a wide range of industrial biotechnological applications. These enzymes are generally produced by psychrophilic microorganisms, which usually survive at temperatures around $5{ }^{\circ} \mathrm{C}$, and generally display high catalytic activity at low temperatures between $0^{\circ}$ and $30^{\circ}[134,135]$. Recently, new reported applications of lipase have been implemented, such as ring-opening polymerization [136]. Usually, catalytic activities are grouped under two features: synthesis and hydrolysis. The main synthesis reactions can be classified as alcoholics, acidolysis, aminolysis, esterification, and interesterification, as stated in Figure 7 [137]. For the lipase catalyzed Michael addition reaction, various catalytic mechanisms are put forward. These reactions imply the activation of $\alpha, \beta$-unsaturated carbonyl compound as an electrophile, with an additional nucleophile. A new mechanism has been proposed for catalyzing the addition of benzylamine to methyl crotonate by Candida antarctica lipase B. This mechanism implies the formation of the oxyanion hole by Thr40 and Gln106 for stabilizing the negative charge of the transition state, which favored the generation of the electrophilic carbocation. On its side, a couple of catalytic triads-His224-Asp187-favor proton dissociation of the amine group to generate an activated nucleophile, and enable proton transferring during the catalytic mechanism [138]. Lipid modification is another main lipase application used for designing natural lipids to meet nutritional properties, such as synthesizing the cocoa-butter equivalent of palm oil and stearic acid. Cocoa-butter has special properties, such as a melting temperature between $25-35^{\circ} \mathrm{C}$ and has a crystalline form [139]. Masayama et al. [140] have reported the ability for synthesizing Phosphatidylinositol by one of Streptomyces Phospholipase D mutants after altering enzymes substrate specificity. Enhancing Candida antarctica A lipase selectivity by rational design has implemented in the production of polymers or surfactants, as the modified variants have higher selectivity toward erucic acid (C22:1) from plant oil or its ethyl ester derivative [141]. Furthermore, modifying Candida antarctica A lipase selectivity for medium-chain fatty acids (MCFAs: C6-C10) by rational design has been exploited in food additives, as it provides quick access to energy, and has less implicated in the accumulation of body fat [142]. In the food industry, the immobilized lipases from Staphylococcus xylosus, Candida antarctica, Staphylococcus warneri, and Mucor miehei were used in the production of short-chain flavored thioesters and flavored esters. Additionally, the use of Candida rugosa lipase in the production of flavor compounds, such as ethyl caprylate, the production of ice creams, and the food and flavor industry, was recently reported $[143,144]$. Recently, Zorn et al. [145] reported improving the chain length of mono-unsaturated fatty acids from Camelina and Crambe oil ethyl ester derivatives by exploiting semi-rationally designed Candida antarctica Lipase A.

Reversing Candida antarctica A lipase enantioselectivity by directed evolution has successfully been implemented in the drug industry, as the new variants have shown different enantioselectivity against R-substituted esters [146]. The therapeutics chemical industry is also catalyzed by lipase, such as manufacturing antibacterial compounds. Candida rugosa lipase catalyzes the enzymatic resolution of (S) - and (R)-elvirol and their derivatives (S) - (+) and (R) -(-)-curcuphenol 8, which exhibits antibacterial activity against Staphylococcus aureus, and Vibrio anguillarum. However, the (S) - (+) - enantiomer has the activity to inhibit the gastric H/K-ATPase [147]. Hence, in the pharmaceutical application, the engineered variant of the Thermomyces lanuginosus (Humicola lanuginosa) lipase comprising amino acids 1-269 of SEQ ID NO: 1, combined with a protease, and/or an amylase were used in medical indications, as treatment of diabetes type I, diabetes type II, digestive disorders, pancreatic exocrine insufficiency (PEI), cystic fibrosis, and pancreatitis. The novel lipases have improved efficacy in vivo and are stable in the presence of bile salts, and stable against protease-degradation [148]. Recently, the monoglyceride lipase has been recognized to be a promising drug targeting many disorders, such as neurodegenerative, cancer, and inflammatory diseases [149] In the nanomedicine field, Sn2 lipase labile phospholipid prodrugs, together with contact-facilitated drug delivery, are exploited in the prevention of premature drug diffusional loss during circulation and for increasing target cell bioavailability [150]. In the medicine field, especially, in cancer therapy and prevention, a novel application potential of lipases was reported [151]. 


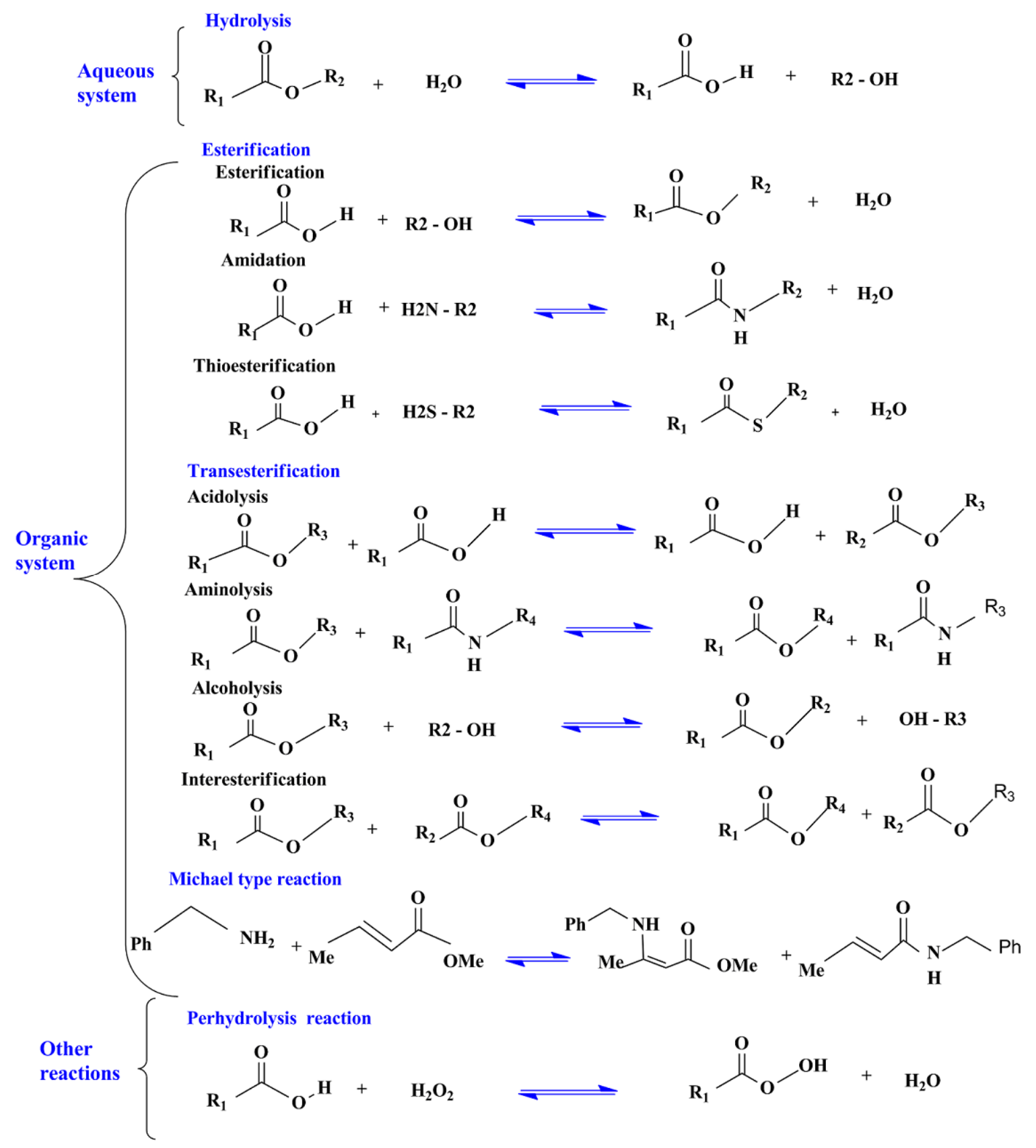

Figure 7. Reaction catalyzed by lipase in aqueous and organic systems [137].

By single catalyzing transesterification of lipase in organic solvents, a renewable energy source for public transportation fuel is produced. This fuel originates from various plant oil by converting vegetable oil to methyl- or short-chain alcohol esters [152]. Lipase from Burkholderia cepacia has extensively been used in biodiesel production by catalyzing non-edible oil and castor oil transesterification [153]. Additionally, implementing lipases from Fusarium heterosporum expressed in Aspergillus niger in biodiesel synthesis was found to be beneficial by eliminating the phospholipid concentration in oils used for this purpose [154]. Another supported study achieved by Du et al. [155] reported the possibility of converting phospholipids-containing oils to biodiesel. This lipase mediated process accelerated production three-fold, and enhanced the efficiency of deriving biodiesel from waste oil. Lipase also plays an essential role in bioremediation, as it could be used for the treatment of the lipid processing factories and restaurant wastes, such as Staphylococcus pasteuri COM-4A, B lipase, Arthrobacter sp, and B. subtilis COM-B6 lipase [156]. Lipases from Acinetobacter sp, C. rugosa, Bacillus sp, Pseudomonas 
sp were also been used in the skimmed fat-rich impurities digestion [157]. In the anaerobic treatment of industrial wastewater, food waste [158], grease from wool [159], dairy waste [160], wastewater from oil mills [156], and manure [161]. Bojsen et al. [162] reported enhancing enzyme activity and stability by combining two homologous genes encoding the high active Fusarium oxysporum phospholipase and high stable Thermomyces lanuginosus lipase, which resulted in a novel improved phospholipase used in catalyzing the glycerolysis of palm oil to produce diacylglycerol (DAG). This product is marketed for degumming edible oil (Lecitase ultra ${ }^{\mathrm{TM}}$, Novozymes A/S). In the fatty acid derived from palm oil synthesis, the Candida antarctica lipase A acyltransferase activity has been implemented, even in the presence of $5-10 \%(w / w)$ water [163]. The Novozyme 435 lipase has been efficiently implemented in free fatty acids with octanol esterification to produce octyl esters, hence, the modification of vegetable oils to form bio lubricant components can be successfully achieved by exploiting lipase-catalyzed transesterification, esterification, epoxidation reactions [164]. In the cosmetic industry, lipase derived from $P$. cepacia and $P$. fluorescens has been involved in producing the menthol esters that provide a peppermint flavor in shaving creams and mouthwashes [165]. The esterification catalyzed by lipase has been used in synthesizing esters derived from wax, ellagic acid, cinnamic acid, and ferulic acid, as these products can be involved in cosmetics and sunscreens, precursors of pharmaceuticals and flavor/fragrance compounds industries [143,166,167].

\section{Major Challenges of Implementing Wild Type Lipase in Industrial Application}

Despite the breakthrough in microbial enzyme identification, purification, and implementation, the diverse industrial demands of improved lipases properties, such as enhancing thermostability, enantio-regio-stereoselectivity, productivity, activity, and stability in different organic solvents, have emerged in various sectors. Increasing demand for consumer goods, natural source depletion, cost reduction, and environmental safety, all these driving factors have motivated the use of microbial enzymes in industrial applications [168]. In 2014, the global market for industrial enzymes was estimated at USD 4.2 billion, and expected to develop at a compound annual growth rate (CAGR) of approximately USD 6.2 billion in 2020 [169]. For industrial satisfaction, there is a great necessity to engineer lipases both in the aspect of quantity and quality at the lab scale, as available lipase performance is not always sufficient for an industrial application, and the majority of enzymes have sub-optimal characteristics for processing conditions, such as temperature, pressure, salinity, and $\mathrm{pH}[170,171]$. However, screening for new lipases requires many time consuming and expensive procedures, starting from screening and isolating the producing bacteria, identifying and optimizing the lipase activity, determining the molecular weight, sequencing, cloning, and screening for a suitable host to purification. For enzyme purification, several methods were used, and these methods were typically dependent on several nonspecific techniques, such as precipitation; gel filtration; hydrophobic interaction chromatography; affinity chromatography, which has been used to shorten the number of individual purifications; and finally, ion-exchange chromatography [172]. However, many factors affect protein purification, such as: (i) a high concentration of protein which often causes protein precipitation and aggregation, as the addition of charged amino acids affects the protein solubility; (ii) high imidazole concentration, as it might affect the protein crystallization; (iii) high protein concentration during dialysis, which may result in protein participation, (iv) a suitable expression system, which is related to protein solubility and properly folded and activity; (v) the cysteine-containing proteins, which mainly affect in purification due to the cross-linking of thiol groups that causes oxidation then aggregation; (vi) isoelectric point $(\mathrm{pI})$ and $\mathrm{pH}$, which affect protein stability and solubility; (vii) temperature and salt concentration, which might affect protein solubility and result in protein aggregation; (viii) finally, the mutation in a single domain, point mutation, truncated, or subunits of multimeric proteins, rather than the native proteins might be a helpful factor in protein solubility and crystallization [173].

Lipase like Novozym 435 has been exploited in lots of industrial applications, such as esterification, transesterification of many chemical and fine chemical products, producing pure optical enantiomers, polymer production and modification, food modification technology, and biodiesel production, due to 
the excellent catalytic prosperity and stability in different organic media. However, this golden biocatalyst has many serious problems, as this catalyst is immobilized by using the hydrophobic "Lewatit" via interfacial activation. This support can retain hydrophilic by-products, such as retaining glycerin in biodiesel production and water in esterification, which will result in enzyme inactivation, because of the formation of water or glycerin layers inside the enzyme. Another problem related to the immobilized enzyme support, is that at the high-temperature reaction in the presence of organic co-solvent or detergent, the enzyme disassociates the support particles [174].

\section{Enzyme Engineering Approaches}

Protein engineering generally involves the amino acid sequence modification at the DNA sequence level by various means of genetic techniques or chemicals. The produced protein is then tested for an optimal, novel, or improved catalytic and/or physical properties. However, several points should be considered to determine which protein engineering strategy should be implemented. This involves three steps. First, determining the protein changes (engineering strategy) such as randomization or rational design. Second, making these changes and, finally, evaluating the properties of the improved protein (selection or screening). Recently, many concepts have been adapted for applying successful protein engineering strategies, such as determining the location of changes throughout the protein or at selected regions (near the active site, at flexible sites, sites identified by structure-based modeling or by sequence comparisons). This substitution could involve one amino acid, inserting extra amino acids, changing the location of the amino acid at the end or deleting them. Enhancing protein thermostability is an example of amino acid substitution, and this can be achieved by removing glycine, or introducing proline at the loop area, or increasing protein stability by designing specific interaction (salt bridges or disulfide bonds). Another concept that should be considered for protein engineering is the mutagenesis method, such as error-prone, saturation mutagenesis, DNA shuffling, and simultaneous mutagenesis of many sites. In addition, the screening methods are considered an important concept, as they include selection for growth, high-throughput screening, substrate analog or true substrate, true reaction condition, exhaustive screening or partial screening library [175]. There are two basic mutagenesis approaches, and it is sometimes appropriate to combine both approaches.

\subsection{Directed Evolution}

Direct evolution principles constitute two steps: the generation of random mutant library and screening the required variant with a suitable screening system. To create mutant libraries there are two variant strategies, namely non-recombining epPCR and recombining of the different genes (DNA shuffling) [6]. The most widely used technique for direct evolution is non-recombining epPCR, which uses an unbalanced concentration of $\mathrm{dNTP}$ and $\mathrm{Mg}^{2+}$, which works as DNA polymerase cofactor to enhance DNA processing [176]. To perform high-fidelity PCR with Taq polymerase, reactions the $\mathrm{MgCl}_{2}$ concentration should not be in large excess over the total concentration of dNTP substrate [177]. This will result in substantially increasing the rate of errors in the gene codon [178]. In the pharmaceutical industry, a modified esterase from Bacillus subtilis is used to hydrolyze pnitrobenzyl ester bonds in the organic solvents. This reaction involves removing the protecting groups introduced during antibiotic (cephalosporins) synthesis. After four generations of random mutagenesis, the specific enzyme activity increases 30-fold, followed by DNA recombination [179].

The first recombining method (DNA shuffling) was developed by Stemmer [178] and used in DNA degradation. This method used DNAse for catalyzing DNA degradation, and subsequently followed by recombination of the fragment without primers (self-priming PCR), whereas the second epPCR needed for primers. The range of mutant varies from (104-108) with all random mutagenesis methods, but a highly reliable screening or selection system is required to identify the desired improved property [180]. In protein engineering in numerous applications, directed evolution is a very useful method [181]. The creation of regioselectivity and enantio-diastereo enzymes as catalysts for asymmetric transformations is achieved by engineering the enzyme binding pocket. This method was 
used as a choice by implementing (iterative) saturation mutagenesis for amino acid randomization at the targeting area [182]. There are two novel approaches used for solving an effectivity problem. One implements a single amino acid as a block building by randomization of the 10-residue site, while another uses nine amino acid residues by employing each residue for different amino acid residues [183]. A smart technique was presented by Seeling and Szostak [184], in which the enzyme was first selected for its activity and the activity improved by direct evolution. In this technique, the authors developed a new method to aid them in their resulted library screening. This technique involved the generation of DNA library and subsequently transcribed into mRNA. Before in vitro translation, the $3^{\prime}$ end of mRNA was cross-linked to a modified oligonucleotide containing puromycin (tRNA resembles antibiotic), resulting in an mRNA-displayed protein. Subsequently, via the reverse transcription of the mRNA to cDNA by using a substrate linked primer, the mRNA displayed protein was linked to the reaction substrate to carry out the selection process. By converting the substrate into the required product, the active enzyme then can be selected. Finally, the cDNA of the active enzyme is isolated and used for further rounds of the direct evolution process.

\subsection{Rational Design}

This approach is based on the knowledge of possible relationships of structure, sequence, function, and catalytic mechanisms of protein to allow the prediction of amino acid residues needed for mutation. Mutations are introduced at a specific place of gene encoding protein. There are two methods for site directed mutagenesis. The first one called "overlap extension". The second method of site-directed mutagenesis uses commercial "QuikChange Site Directed Mutagenesis Kit", and is called whole plasmid single round PCR [185]. Many predictive computational algorithms have been developed and used for predicting possible effective target [186]. To predict the changes required to modify certain protein properties, deep knowledge of the structure and energy function is required [187]. Many enzymes have been rationally redesigned for different purposes such as: (I) increasing the enzyme thermostability by replacing glycine with proline [188], or by deletion N-terminal domain [35]; II) enhancing Candida antarctica lipase B (CalB) stability in a hydrophilic organic solvent by generating an additional enzyme surface hydrogen bonds [189]; (III) replacing the high B-factor region [190]; (IV) enhancing substrate enantioselectivity or substrate specificity; and (V) introducing catalytic promiscuity by introducing a new reaction specificity in an enzyme [191]. This method has been approved as it achieves many important goals. It is simple and well-established; on the other hand, it is difficult to get a precise knowledge of protein efficient hotspots, or the effect of different mutations. Site-directed mutagenesis has been used in changing the nucleotide sequence of a cloned DNA fragment using synthetic oligonucleotides. The breakthrough in molecular modeling software and the new generation of computational tools and databases have helped non-experts to perform protein engineering by rational design. In this mutagenesis approach to make the desired changes sometimes sequence alignment is needed for supporting the selection of mutant positions, especially when the protein belongs to a well characterized large family, as then the planned substitutions (mutation) effects can be predicted [192]. Depending on homology modeling, 72,000 protein sequences have had their structures solved. The computational biology scientists developed algorithms for protein 3D structure prediction from their amino acids sequencing similarities. This prediction is based on one effective approach using an already known structure template sharing ( $40 \%$ and up) similarity. Furthermore, the use of in silico simulation (molecular modeling) to simulate the behavior of the molecule-which depends on using several equations and algorithms describing inter and intra-molecular interactions-has been widely used for DNA and protein simulations. Docking is another computational technique that has been used for binding affinity estimation and protein conformation prediction, which has improved the rational design [193]. 


\subsection{Combined Engineering Strategies}

Combining rational protein design and directed evolution procedures have been evolved for producing smaller libraries [194]. Based on the enzyme structure information these methods were used to targets specific enzyme regions and residues in each evolution cycle. According to this approach, many studies have been extensively using saturation mutagenesis procedures for many enzyme properties improvement. This method is based on the randomization of all amino acids at a specific position, or on the randomization of two or more positions in an enzyme simultaneously $[195,196]$. In this case, the screening process is faster as the modified sequence space is small. A more efficient method known as Iterative Saturation Mutagenesis (ISM) for directed evolution was introduced for producing high functional enzymes. [196,197]. Based on the resulted protein structure, applying ISM at defined chosen sites of an enzyme has extremely reduced the screening effort and molecular biological work necessity [198]. Gene Site Saturation Mutagenesis (GSSM) is a more developed approach, which provides high throughput screening methods [199]. Computational protein designing tools are getting more and more attention in recent years, as a novel strategy to predict the effects of the mutations on the structure, function, or stability of enzyme variants resulted from utilizing in silico approaches [200].

A set of computational programs have been designed for the systematic analysis of the relationship between lipases sequence, structure, function, and related proteins; The Data Warehouse System (DWARF) [201], the alpha/beta-hydrolase fold 3DM Database (ABHDB) [202], or Lipase Engineering Database (LED) [203]. These databases integrate sequence, structure, and annotation information available in public databases like PDB [204], GenBank [205], and others, being useful tools for the designing of enzyme variants with improved properties by identifying functionally relevant residues apart from the active site amino acids [203]. The introduction of the B-factor criterion (B-FITTER) [186], is another tool used to identify the amino acid with a high average B-factor, which means that this amino acid residue has a degree of flexibility that corresponds to low thermostability [206]. Juhl and co-workers exploited bioinformatics to generate improved Candida antarctica lipase B (CAL-B), accepting esters with branched and sterically demanding acids [207]. They generated 2400 CAL-B variants an in silico library and screened by substrate docking. Virtual screening resulted in nine variants with single substituted amino acid achieved by site directed mutagenesis. Among the nine resulted variants only one showed higher activity than the wild type toward branched acids but not toward sterically demanding acids. This work showed the advantages of implementing in silico approaches to predict improved variants, thus reducing the high throughput screening assays. Another successful study introduced by Ruslan and co-workers, exploited the computational protein tool, namely I-Mutant 2.0 resulted in improving the Geobacillus zalihae T1 lipase thermostability by introducing an ion-pair in the inter-loop [208]. Furthermore, powerful computational tools (MODIP and DbD v1.20) were used by Le and co-workers to predict the possible disulfide bonds in Candida antarctica lipase B for improving thermostability. They predicted five residue pairs to substitute to cysteine. The resulted CAL-B variant maintained its catalytic efficiency and improved thermostability as the half-life was higher 4.5-fold, compared to that of the wild type enzyme [190].

Lipase derived from Candida antarctica B and Bacillus pumilus have engineered by molecular dynamic (MD) simulations and direct evolution to enhance activity and thermostability [209,210]]. Recently, findings reported using ultrasound for treating lipase from Thermomyces lanuginosus (Lipozyme TL-IM), which resulted in significantly improve in biodiesel production, as the modified lipase reduced the quantity of excess methanol used in this process [211]. Site saturation mutagenesis and high-throughput screening techniques were used in another study for engineering Thermomyces lanuginosus DSM 10635 lipase to improve its activity. The resulted catalyst effectively used in the chiral intermediate of Pregabalin biosynthesis [212]]. Engineering psychrophilic lipase isolated from an arctic bacterium, Bacillus pumilus by rational design based on the 3D-structure model technique to improve activity, resulted in two novel mutants with significant activities improvement, as compared to that of the wild type [213]. Moreover, using the metabolic engineering techniques of lipase from 
Burkholderia cepacia highly increased the lipase production 34-fold compared to a wild type after cloning and expressing in Lactococcus lactis [214].

The optimization of many enzymes by using response surface methodology and statistical design of experiment studies are essential for improving the process efficiency at various scales of the industrial process. In the pharmaceutical and chemical industries, the industrial scale-up of lipase-catalyzed bioprocesses find immense applications, as led to synthesis biotransformed end and chiral product. The synthesized product can provide eco-friendly alternatives to the organo and metallo catalysis that require extreme operating conditions. The scale-up of some pharmaceutical lipase included several biocatalysis reactions, such as the synthesis of wax esters, cetylricinoleate, or myristylmyristate for cosmetics and $(1 S, 3 S)$-3-aminocyclohexanol, as well as the synthesis of diltiazem by resolution of chiral precursors products [5].

\section{Targeting Loop and Binding Area for Engineering Specificity}

Changing enzyme substrate selectivity is one of the most required modifications in engineering catalysts. Natural enzymes do not show a wide substrate acceptance range or high catalytic activity towards different substrates, at the same time they are highly specific either in the type of reaction they catalyze, and the nature of the substrate they utilize. Thus, one of the most important industrial needs is modifying enzyme selectivity to exhibit broad substrate specificity. This modifying process falls into three categories: expanding, narrowing substrate specificity, and completely switching the specificity towards novel substrates [215]. In silico analyses have been used for predictions of enzymes hotspot to engineer new desired properties, and these have helped the evaluation of predicted hotspots, and determining suitable amino acids for substitution [216]. Recently, many studies have indicated that targeting sites lining the binding pocket of an enzyme by site saturation mutagenesis is particularly effective [197].

Many researchers have successfully improved or changed many enzymes' specificity by manipulating the amino acids around the pocket binding area, for example, in Pseudomonas cepacia, changing the Tyr4, Tyr29, Tyr45, Tyr95, and Asp36, Asp55 that line the pocket binding area improved the Pseudomonas cepacia enantio and regioselectivity toward p-NPP-(p-nitrophenyl palmitate) secondary alcohol about 6-fold [115]. Damnjanovic et al. [217] reported enhancing Streptomyces antibioticus phospholipase D specificity toward Phosphatidylinositol (PI) by subjecting the binding site's four residues to saturation mutagenesis. Another study has shown that targeting the substrate binding site of Candida antarctica Lipase A had improved acyltransferase activity [218]. Hence, Jan et al. [219] had also reported improving Pseudozyma antarctica lipase A (CAL-A) acyltransferase activity by targeting a substrate binding site. Substrate entrance enzyme tunnel also was selected as a target for engineering substrate specificity of Pseudomonas sp acidic lipase toward long-chain C-18 substrate by applying saturation mutagenesis [73]. Furthermore, targeting Candida rugosa lipase access channel by substituting the small amino acid residues using site-directed mutagenesis with a bulky one has shifted the lipase chain length specificity toward short-chain [220]. Other studies have shown that substituting the lid region of lipases changes lipase activity, enantioselectivity, thermostability, stability, and enhanced catalytic efficiency [221]. However, the complete substitution of the lipase lid region with the same sequence of the esterase lid region decreases interfacial activity and increases the enzyme activity toward water-soluble substrate activity (Esterase property) [222]. Recently, findings reported by Wikmark et al. [223] show that removing the lid region of Candida antarctica lipase A has retained the enzyme's functional properties activity, stability, stereoselectivity, and substrate specificity-without interfacial activation. The hinge region is another part of the lid which affects lipase selectivity. This has been depicted by a mutation in this area (lid hinge) and resulted in improved lipase chain length specificity and thermostability of the enzyme [224] Table 3 indicates that enzyme engineering by rational design at the lid, and substrate binding area resulted in enzyme specificity modification, and it will help in implementing this approach at these structural points to produce a novel biocatalyst. 
Table 3. Selected examples of lipases with improved protein specificity by targeting different structure areas.

\begin{tabular}{|c|c|c|c|c|}
\hline Enzyme Origin & Mutagenesis Method & Structural Target & Improved Property & References \\
\hline $\begin{array}{c}\text { Candida antarctica } \\
\text { lipase } \mathrm{A}\end{array}$ & $\begin{array}{l}\text { Saturation mutagenesis \& } \\
\text { Randomization }\end{array}$ & $\begin{array}{l}\text { Substrate binding } \\
\text { area }\end{array}$ & Substrate selectivity & [75] \\
\hline $\begin{array}{l}\text { Candida antarctica } \\
\text { lipase A }\end{array}$ & $\begin{array}{l}\text { Saturation mutagenesis } \\
\text { combinatorial active-site } \\
\text { saturation test (CAST) }\end{array}$ & $\begin{array}{l}\text { Substrate binding } \\
\text { area }\end{array}$ & Enantioselectivity & [225] \\
\hline $\begin{array}{l}\text { Penicillium expansum } \\
\text { lipase }\end{array}$ & Saturation mutagenesis & Loop helix (lid) & Substrate selectivity & [224] \\
\hline $\begin{array}{c}\text { Burkholderia cepacia } \\
\text { lipase }\end{array}$ & Rational design & $\begin{array}{l}\text { Binding access } \\
\text { channel }\end{array}$ & Enantioselectivity & [226] \\
\hline $\begin{array}{c}\text { Thermomyces lanuginosus } \\
\text { lipase }\end{array}$ & Rational design & Loop helix (lid) & Substrate selectivity & [222] \\
\hline $\begin{array}{c}\text { Pseudomonas sp } \\
\text { lipase }\end{array}$ & Saturation mutagenesis & $\begin{array}{l}\text { Binding access } \\
\text { channel }\end{array}$ & Substrate specificity & [73] \\
\hline $\begin{array}{l}\text { Candida antarctica } \\
\text { lipase A }\end{array}$ & $\begin{array}{c}\text { Combinatorial saturation } \\
\text { test (CAST) }\end{array}$ & $\begin{array}{l}\text { Substrate binding } \\
\text { area }\end{array}$ & Enantioselectivity & [146] \\
\hline $\begin{array}{l}\text { Burkholderia cepacia } \\
\text { lipase }\end{array}$ & $\begin{array}{l}\text { Combinatorial site } \\
\text { directed mutagenesis }\end{array}$ & $\begin{array}{l}\text { Binding access } \\
\text { channel }\end{array}$ & Substrate selectivity & [227] \\
\hline Human (glyoxalase II) & $\begin{array}{c}\text { Rational design(insertion } \\
\text { +deletion) }\end{array}$ & $\begin{array}{l}\text { Substrate binding } \\
\text { area }\end{array}$ & Substrate selectivity & [228] \\
\hline $\begin{array}{c}\text { Pseudomonas fluorescens } \\
\text { (esterase) }\end{array}$ & Rational design & $\begin{array}{l}\text { Substrate binding } \\
\text { area }\end{array}$ & Substrate selectivity & [229] \\
\hline $\begin{array}{l}\text { Pseudomonas fragi } \\
\text { lipase }\end{array}$ & Rational design & Loop helix (lid) & Substrate selectivity & [230] \\
\hline $\begin{array}{l}\text { Candida antarctica } \\
\text { lipase }\end{array}$ & Semi rational design & $\begin{array}{l}\text { Binding access } \\
\text { channel }\end{array}$ & Chain length selectivity & [145] \\
\hline $\begin{array}{c}\text { Streptomyces antibioticus } \\
\text { PLD } \\
\text { lipase }\end{array}$ & Semi rational design & $\begin{array}{l}\text { Substrate binding } \\
\text { area }\end{array}$ & Chain length selectivity & [231] \\
\hline $\begin{array}{l}\text { Staphylococcus epidermidis } \\
\text { lipase }\end{array}$ & Rational design & $\begin{array}{l}\text { Substrate binding } \\
\text { area }\end{array}$ & Substrate specificity & [232] \\
\hline Nicotiana tabacum esterase & Rational design & $\begin{array}{l}\text { Substrate binding } \\
\text { area }\end{array}$ & Substrate specificity & [233] \\
\hline $\begin{array}{c}\text { Candida antarctica B } \\
\text { lipase }\end{array}$ & Rational design & $\begin{array}{l}\text { Substrate binding } \\
\text { area }\end{array}$ & Enantioselectivity & [234] \\
\hline $\begin{array}{c}\text { Candida antarctica B } \\
\text { lipase }\end{array}$ & Rational design & $\begin{array}{l}\text { Substrate binding } \\
\text { area }\end{array}$ & Substrate specificity & [235] \\
\hline $\begin{array}{c}\text { Candida antarctica B } \\
\text { lipase }\end{array}$ & Rational design & $\begin{array}{l}\text { Substrate binding } \\
\text { area }\end{array}$ & Substrate specificity & [236] \\
\hline $\begin{array}{c}\text { Candida antarctica B } \\
\text { lipase }\end{array}$ & Rational design & $\begin{array}{l}\text { Substrate binding } \\
\text { area }\end{array}$ & Enantioselectivity & [237] \\
\hline $\begin{array}{l}\text { Pseudomonas fragi } \\
\text { lipase }\end{array}$ & Rational design & Loop helix (lid) & Chain length selectivity & [55]] \\
\hline $\begin{array}{l}\text { Rhizopus chinensis } \\
\text { lipase }\end{array}$ & Rational design & Loop helix (lid) & Chain length selectivity & [238] \\
\hline $\begin{array}{l}\text { Rhizopus chinensis } \\
\text { lipase }\end{array}$ & Rational design & Loop helix (lid) & substrate specificity & [221] \\
\hline $\begin{array}{c}\text { Pseudomonas aeruginosa } \\
\text { lipase }\end{array}$ & directed evolution & $\begin{array}{l}\text { Substrate binding } \\
\text { area }\end{array}$ & Substrate specificity & [239] \\
\hline $\begin{array}{c}\text { Bacillus thermocatenulatus } \\
\text { lipase }\end{array}$ & Rational design & $\begin{array}{l}\text { Substrate binding } \\
\text { area }\end{array}$ & Chain length selectivity & [240] \\
\hline $\begin{array}{l}\text { Streptomyces antibioticus } \\
\text { phospholipase }\end{array}$ & $\begin{array}{l}\text { Site-saturation } \\
\text { mutagenesis }\end{array}$ & $\begin{array}{l}\text { Substrate binding } \\
\text { area }\end{array}$ & Substrate specificity & [217] \\
\hline $\begin{array}{l}\text { Candida antarctica } \\
\text { lipase A }\end{array}$ & Rational design & $\begin{array}{l}\text { Substrate binding } \\
\text { area }\end{array}$ & Substrate specificity & [218] \\
\hline $\begin{array}{c}\text { Candida antarctica } \\
\text { lipase A }\end{array}$ & Rational design & $\begin{array}{l}\text { Binding access } \\
\text { channel }\end{array}$ & Chain length selectivity & [142] \\
\hline
\end{tabular}


Table 3. Cont.

\begin{tabular}{|c|c|c|c|c|}
\hline Enzyme Origin & Mutagenesis Method & Structural Target & Improved Property & References \\
\hline Geobacillus sp. lipase & Rational design & $\begin{array}{l}\text { Binding access } \\
\text { channel }\end{array}$ & Substrate specificity & [241] \\
\hline $\begin{array}{c}\text { Candida antarctica A } \\
\text { lipase }\end{array}$ & $\begin{array}{l}\text { Combinatorial site } \\
\text { directed mutagenesis }\end{array}$ & $\begin{array}{l}\text { Substrate binding } \\
\text { area }\end{array}$ & Enantioselectivity & [242] \\
\hline $\begin{array}{c}\text { Candida antarctica A } \\
\text { lipase }\end{array}$ & Rational design & $\begin{array}{l}\text { Substrate binding } \\
\text { area }\end{array}$ & Substrate specificity & [141] \\
\hline $\begin{array}{c}\text { Pseudomonas aeruginosa } \\
\text { lipase }\end{array}$ & $\begin{array}{c}\text { ep-PCR and saturation } \\
\text { mutagenesis }\end{array}$ & $\begin{array}{l}\text { Substrate binding } \\
\text { area }\end{array}$ & Enantioselectivity & [243] \\
\hline $\begin{array}{c}\text { Pseudomonas aeruginosa } \\
\text { lipase }\end{array}$ & $\begin{array}{c}\text { Combinatorial saturation } \\
\text { test }(\mathrm{CAST})\end{array}$ & $\begin{array}{l}\text { Substrate binding } \\
\text { area }\end{array}$ & Substrate specificity & [244] \\
\hline $\begin{array}{c}\text { Rhizopus delemar } \\
\text { lipase }\end{array}$ & Rational design & $\begin{array}{l}\text { Substrate binding } \\
\text { area }\end{array}$ & Chain length selectivity & [245] \\
\hline $\begin{array}{l}\text { Rhizopus delemar } \\
\text { lipase }\end{array}$ & Rational design & $\begin{array}{l}\text { Substrate binding } \\
\text { area }\end{array}$ & Chain length selectivity & [246] \\
\hline $\begin{array}{l}\text { Bacillus subtilis } \\
\text { lipase A }\end{array}$ & Saturation mutagenesis & $\begin{array}{l}\text { Substrate binding } \\
\text { area }\end{array}$ & Enantioselectivity & [247] \\
\hline $\begin{array}{c}\text { Alicyclobacillus acidocaldarius } \\
\text { esterase } \\
\text { EST2 }\end{array}$ & $\begin{array}{l}\text { directed evolution } \\
\text { ep-PCR }\end{array}$ & $\begin{array}{l}\text { Substrate binding } \\
\text { area }\end{array}$ & $\begin{array}{l}\text { Chain length selectivity; } \\
\text { sn2 specificity }\end{array}$ & [248]] \\
\hline
\end{tabular}

\section{Conclusions and Future Prospective}

The role of every amino acid residue around the binding pocket (active site) and lid region is very complex, because they involve different and specific interaction with substrate molecules. Another prospect is that lipase reactions take place at an interfacial state, which affects the quality of the obtained products. Also, the electrical equilibrium after replacing the amino acid residue around the binding area, and the lid (flap), should be considered when applying different mutagenesis approaches, as it affects the binding energy and the interfacial activation state. With enough knowledge, reconstruction, and redesigning, novel biocatalysts (lipases) will facilitate the construction of new enantiomers used in medicine and other applications. Furthermore, genome-editing and synthetic biology techniques could perform the construction of metabolic pathway, which might be implemented in the production of useful lipase from microbial origins. With the evolution of molecular enzymology and lipase specificity, these two will be promising tools to support synthesizing new material with desirable structures and properties.

Author Contributions: S.H.A., R.N.Z.R.A.R. and M.M. wrote the manuscript; S.N.H.I. and A.L.T. assisted in software usage and Figures design, M.S.b.M.A., F.b.M.S. and N.D.b.M.N. read and contribute to manuscript revision. All authors have read and agreed to the published version of the manuscript.

Funding: This research was supported financially by the Ministry of Education, Malaysia. (FRGS/1/2019/STGO5/ UPM/01/1/01-01-19-2178FR).

Conflicts of Interest: The authors declare that the research was conducted in the absence of any commercial or financial relationships that could be construed as a potential conflict of interest.

\section{References}

1. Su, F.; Li, G.; Fan, Y.; Yan, Y. Enhanced performance of lipase via microcapsulation and its application in biodiesel preparation. Sci. Rep. 2016, 6, 1-12. [CrossRef] [PubMed]

2. Bornscheuer, U.T.; Kazlauskas, R.J. Hydrolases in Organic Synthesis: Regio- and Stereoselective Biotransformations; John Wiley \& Sons: New Jersey, NJ, USA, 2006; ISBN 3527607129.

3. Zaks, A.; Klibanov, A.M. Enzyme-catalyzed processes in organic solvents. Proc. Natl. Acad. Sci. USA 1985, 82, 3192-3196. [CrossRef] [PubMed]

4. Reetz, M.T. Lipases as practical biocatalysts. Curr. Opin. Chem. Biol. 2002, 6, 145-150. [CrossRef]

5. Sarmah, N.; Revathi, D.; Sheelu, G.; Yamuna Rani, K.; Sridhar, S.; Mehtab, V.; Sumana, C. Recent advances on sources and industrial applications of lipases. Biotechnol. Prog. 2018, 34, 5-28. [CrossRef] 
6. Bornscheuer, U.T. Alteration of lipase properties by protein engineering methods. OCL Ol. Corps Gras Lipides 2008, 15, 184-188. [CrossRef]

7. Pleiss, J.; Fischer, M.; Schmid, R.D. Anatomy of lipase binding sites: The scissile fatty acid binding site. Chem. Phys. Lipids 1998, 93, 67-80. [CrossRef]

8. Jaeger, K.-E.; Eggert, T. Lipases for biotechnology. Curr. Opin. Biotechnol. 2002, 13, 390-397. [CrossRef]

9. Richmond, G.S.; Smith, T.K. Phospholipases A1. Int. J. Mol. Sci. 2011, 12, 588-612. [CrossRef] [PubMed]

10. Ali, Y.B.; Verger, R.; Abousalham, A. Lipases or esterases: Does it really matter? Toward a new bio-physico-chemical classification. In Lipases and Phospholipases: Methods and Protocols; Sandoval, G., Ed.; Humana Press: Totowa, NJ, USA, 2012; pp. 31-51. ISBN 978-1-61779-600-5.

11. Chen, S.; Su, L.; Chen, J.; Wu, J. Cutinase: Characteristics, preparation, and application. Biotechnol. Adv. 2013, 31, 1754-1767. [CrossRef] [PubMed]

12. Van Tilbeurgh, H.; Egloff, M.-P.; Martinez, C.; Rugani, N.; Verger, R.; Cambillau, C. Interfacial activation of the lipase-procolipase complex by mixed micelles revealed by X-ray crystallography. Nature 1993, 362, 814-820. [CrossRef] [PubMed]

13. Fojan, P.; Jonson, P.H.; Petersen, M.T.N.; Petersen, S.B. What distinguishes an esterase from a lipase: A novel structural approach. Biochimie 2000, 82, 1033-1041. [CrossRef]

14. Chahiniana, H.; Sarda, L. Distinction between esterases and lipases: Comparative biochemical properties of sequence-related carboxylesterases. Protein Pept. Lett. 2009, 16, 1149-1161. [CrossRef] [PubMed]

15. Jaeger, K.-E.; Ransac, S.; Dijkstra, B.W.; Colson, C.; van Heuvel, M.; Misset, O. Bacterial lipases. FEMS Microbiol. Rev. 1994, 15, 29-63. [CrossRef]

16. Eggert, T.; van Pouderoyen, G.; Dijkstra, B.W.; Jaeger, K.-E. Lipolytic enzymes LipA and LipB from Bacillus subtilis differ in regulation of gene expression, biochemical properties, and three-dimensional structure. FEBS Lett. 2001, 502, 89-92. [CrossRef]

17. Cardenas, F.; De Castro, M.S.; Sanchez-Montero, J.M.; Sinisterra, J.V.; Valmaseda, M.; Elson, S.W.; Alvarez, E. Novel microbial lipases: Catalytic activity in reactions in organic media. Enzym. Microb. Technol. 2001, 28, 145-154. [CrossRef]

18. Arpigny, J.L.; Jaeger, K.E. Bacterial lipolytic enzymes: Classification and properties. Biochem. J. 1999, 343, 177-183. [CrossRef] [PubMed]

19. Kanaya, S.; Koyanagi, T.; Kanaya, E. An esterase from Escherichia coli with a sequence similarity to hormone-sensitive lipase. Biochem. J. 1998, 332, 75-80. [CrossRef]

20. Masomian, M.; Rahman, R.N.Z.R.A.; Salleh, A.B.; Basri, M. Solubility analysis, cloning and functional overexpression of the lipase from Aneurinibacillus thermoaerophilus strain HZ, the first member of true lipases subfamily I.9. Appl. Biochem. Microbiol. 2018, 54, 269-276. [CrossRef]

21. Kim, K.K.; Song, H.K.; Shin, D.H.; Hwang, K.Y.; Choe, S.; Yoo, O.J.; Suh, S.W. Crystal structure of carboxylesterase from Pseudomonas fluorescens, an $\alpha / \beta$ hydrolase with broad substrate specificity. Structure 1997, 5, 1571-1584. [CrossRef]

22. Leow, T.C.; Rahman, R.N.Z.R.A.; Basri, M.; Salleh, A.B. High level expression of thermostable lipase from Geobacillus sp. strain T1. Biosci. Biotechnol. Biochem. 2004, 68, 96-103. [CrossRef]

23. Upton, C. A new family of lipolytic enzymes? Trends Biochem. Sci. 1995, 20, 178-179. [CrossRef]

24. Akoh, C.C.; Lee, G.-C.; Liaw, Y.-C.; Huang, T.-H.; Shaw, J.-F. GDSL family of serine esterases/lipases. Prog. Lipid Res. 2004, 43, 534-552. [CrossRef] [PubMed]

25. Hausmann, S.; Jaeger, K.-E. Lipolytic enzymes from bacteria. In Handbook of Hydrocarbon and Lipid Microbiology; Springer: Berlin, Heidelberg, 2010; ISBN 3540775846.

26. Österlund, T.; Danielsson, B.; Degerman, E.; Contreras, J.A.; Edgren, G.; Davis, R.C.; Schotz, M.C.; Holm, C. Domain-structure analysis of recombinant rat hormone-sensitive lipase. Biochem. J. 1996, 319, 411-420. [CrossRef] [PubMed]

27. Mohamed, Y.M.; Ghazy, M.A.; Sayed, A.; Ouf, A.; El-Dorry, H.; Siam, R. Isolation and characterization of a heavy metal-resistant, thermophilic esterase from a Red Sea Brine Pool. Sci. Rep. 2013, 3, 3358. [CrossRef] [PubMed]

28. Nacke, H.; Will, C.; Herzog, S.; Nowka, B.; Engelhaupt, M.; Daniel, R. Identification of novel lipolytic genes and gene families by screening of metagenomic libraries derived from soil samples of the German Biodiversity Exploratories. FEMS Microbiol. Ecol. 2011, 78, 188-201. [CrossRef] 
29. Galleni, M.; Lindberg, F.; Normark, S.; Cole, S.; Honore, N.; Joris, B.; Frère, J.-M. Sequence and comparative analysis of three Enterobacter cloacae ampC $\beta$-lactamase genes and their products. Biochem. J. 1988, 250, 753-760. [CrossRef]

30. Jacoby, G.A. AmpC $\beta$-lactamases. Clin. Microbiol. Rev. 2009, 22, 161-182. [CrossRef]

31. Nishizawa, M.; Shimizu, M.; Ohkawa, H.; Kanaoka, M. Stereoselective production of (+)-trans-chrysanthemic acid by a microbial esterase: Cloning, nucleotide sequence, and overexpression of the esterase gene of Arthrobacter globiformis in Escherichia Coli. Appl. Environ. Microbiol. 1995, 61, 3208-3215. [CrossRef]

32. Borrelli, G.M.; Trono, D. Recombinant lipases and phospholipases and their use as biocatalysts for industrial applications. Int. J. Mol. Sci. 2015, 16, 20774-20840. [CrossRef]

33. Eggert, T.; Pencreac 'h, G.; Douchet, I.; Verger, R.; Jaeger, K. A novel extracellular esterase from Bacillus subtilis and its conversion to a monoacylglycerol hydrolase. Eur. J. Biochem. 2000, 267, 6459-6469. [CrossRef]

34. Salwoom, L.; Rahman, R.N.Z.R.A.; Salleh, A.B.; Shariff, F.M.; Convey, P.; Pearce, D.; Ali, M.S.M. Isolation, characterisation, and lipase production of a cold-adapted bacterial strain Pseudomonas sp. LSK25 isolated from Signy Island, Antarctica. Molecules 2019, 24, 715. [CrossRef] [PubMed]

35. Latip, W.; Raja Abd Rahman, R.N.Z.R.A.; Leow, A.T.C.; Mohd Shariff, F.; Kamarudin, N.H.A.; Mohamad Ali, M.S. The effect of N-terminal domain removal towards the biochemical and structural features of a thermotolerant lipase from an antarctic Pseudomonas sp. Strain AMS3. Int. J. Mol. Sci. 2018, 19, 560. [CrossRef] [PubMed]

36. Saeed, H.M.; Zaghloul, T.I.; Khalil, I.A.; Abdelbaeth, T.M. Molecular cloning and expression in Escherichia coli of Pseudomonas aeruginosa lipase gene. Biotechnology 2006, 5, 62-68.

37. Van Bloois, E.; Winter, R.T.; Kolmar, H.; Fraaije, M.W. Decorating microbes: Surface display of proteins on Escherichia Coli. Trends Biotechnol. 2011, 29, 79-86. [CrossRef] [PubMed]

38. Hwang, H.T.; Qi, F.; Yuan, C.; Zhao, X.; Ramkrishna, D.; Liu, D.; Varma, A. Lipase-catalyzed process for biodiesel production: Protein engineering and lipase production. Biotechnol. Bioeng. 2014, 111, 639-653. [CrossRef]

39. Tafakori, V.; Torktaz, I.; Doostmohammadi, M.; Ahmadian, G. Microbial cell surface display; its medical and environmental applications. Iran. J. Biotechnol. 2012, 10, 231-239.

40. Tanaka, T.; Yamada, R.; Ogino, C.; Kondo, A. Recent developments in yeast cell surface display toward extended applications in biotechnology. Appl. Microbiol. Biotechnol. 2012, 95, 577-591. [CrossRef] [PubMed]

41. Ogata, K.; Nishikawa, H.; Ohsugi, M. A yeast capable of utilizing methanol. Agric. Biol. Chem. 1969, 33, 1519-1520. [CrossRef]

42. Yan, J.; Zheng, X.; Du, L.; Li, S. Integrated lipase production and in situ biodiesel synthesis in a recombinant Pichia pastoris yeast: An efficient dual biocatalytic system composed of cell free enzymes and whole cell catalysts. Biotechnol. Biofuels 2014, 7, 1-8. [CrossRef]

43. Sharma, R.; Katoch, M.; Srivastava, P.S.; Qazi, G.N. Approaches for refining heterologous protein production in filamentous fungi. World J. Microbiol. Biotechnol. 2009, 25, 2083-2094. [CrossRef]

44. Høegh, I.; Patkar, S.; Halkier, T.; Hansen, M.T. Two lipases from Candida antarctica: Cloning and expression in Aspergillus oryzae. Can. J. Bot. 1995, 73, 869-875. [CrossRef]

45. Fu, C.; Hu, Y.; Xie, F.; Guo, H.; Ashforth, E.J.; Polyak, S.W.; Zhu, B.; Zhang, L. Molecular cloning and characterization of a new cold-active esterase from a deep-sea metagenomic library. Appl. Microbiol. Biotechnol. 2011, 90, 961-970. [CrossRef] [PubMed]

46. Kim, E.Y.; Oh, K.H.; Lee, M.H.; Kang, C.H.; Oh, T.K.; Yoon, J.H. Novel cold-adapted alkaline lipase from an intertidal flat metagenome and proposal for a new family of bacterial lipases. Appl. Environ. Microbiol. 2009, 75, 257-260. [CrossRef] [PubMed]

47. Lee, M.H.; Lee, C.H.; Oh, T.K.; Song, J.K.; Yoon, J.H. Isolation and characterization of a novel lipase from a metagenomic library of tidal flat sediments: Evidence for a new family of bacterial lipases. Appl. Environ. Microbiol. 2006, 72, 7406-7409. [CrossRef]

48. Brzozowski, A.M.; Derewenda, U.; Derewenda, Z.S.; Dodson, G.G.; Lawson, D.M.; Turkenburg, J.P.; Bjorkling, F.; Huge-Jensen, B.; Patkar, S.A.; Thim, L. A model for interfacial activation in lipases from the structure of a fungal lipase-inhibitor complex. Nature 1991, 351, 491-494. [CrossRef]

49. Brocca, S.; Secundo, F.; Ossola, M.; Alberghina, L.; Carrea, G.; Lotti, M. Sequence of the lid affects activity and specificity of Candida rugosa lipase isoenzymes. Protein Sci. 2003, 12, 2312-2319. [CrossRef] 
50. Hamid, T.H.A.; Rahman, R.N.Z.R.A.; Salleh, A.B.; Basri, M. The role of lid in protein-solvent interaction of the simulated solvent stable thermostable lipase from Bacillus strain 42 in water-solvent mixtures. Biotechnol. Biotechnol. Equip. 2009, 23, 1524-1530. [CrossRef]

51. Barbe, S.; Lafaquière, V.; Guieysse, D.; Monsan, P.; Remaud-Siméon, M.; André, I. Insights into lid movements of Burkholderia cepacia lipase inferred from molecular dynamics simulations. Proteins Struct. Funct. Bioinforma. 2009, 77, 509-523. [CrossRef]

52. Reis, P.; Holmberg, K.; Watzke, H.; Leser, M.E.; Miller, R. Lipases at interfaces: A review. Adv. Colloid Interface Sci. 2009, 147, 237-250. [CrossRef]

53. Cajal, Y.; Svendsen, A.; Girona, V.; Patkar, S.A.; Alsina, M.A. Interfacial control of lid opening in Thermomyces lanuginosa lipase. Biochemistry 2000, 39, 413-423. [CrossRef]

54. Verger, R. Enzyme kinetics of lipolysis. In Methods in Enzymology; Elsevier: Amsterdam, The Netherlands; Academic Press: Cambridge, MA, USA, 1980; Volume 64, pp. 340-392. ISBN 0076-6879.

55. Secundo, F.; Carrea, G.; Tarabiono, C.; Gatti-Lafranconi, P.; Brocca, S.; Lotti, M.; Jaeger, K.-E.; Puls, M.; Eggert, T. The lid is a structural and functional determinant of lipase activity and selectivity. J. Mol. Catal. B Enzym. 2006, 39, 166-170. [CrossRef]

56. Tang, L.; Su, M.; Zhu, L.; Chi, L.; Zhang, J.; Zhou, Q. Substitution of Val72 residue alters the enantioselectivity and activity of Penicillium expansum lipase. World J. Microbiol. Biotechnol. 2013, 29, 145-151. [CrossRef]

57. Van Pouderoyen, G.; Eggert, T.; Jaeger, K.E.; Dijkstra, B.W. The crystal structure of Bacillus subtilis lipase: A minimal $\alpha / \beta$ hydrolase fold enzyme. J. Mol. Biol. 2001, 309, 215-226. [CrossRef]

58. Mezzetti, A.; Schrag, J.D.; Cheong, C.S.; Kazlauskas, R.J. Mirror-image packing in enantiomer discrimination: Molecular basis for the enantioselectivity of B. cepacia lipase toward 2-methyl-3-phenyl-1-propanol. Chem. Biol. 2005, 12, 427-437. [CrossRef] [PubMed]

59. Ericsson, D.J.; Kasrayan, A.; Johansson, P.; Bergfors, T.; Sandström, A.G.; Bäckvall, J.E.; Mowbray, S.L. X-ray Structure of Candida antarctica Lipase A Shows a Novel Lid Structure and a Likely Mode of Interfacial Activation. J. Mol. Biol. 2008, 376, 109-119. [CrossRef] [PubMed]

60. Gupta, R.; Kumari, A.; Syal, P.; Singh, Y. Molecular and functional diversity of yeast and fungal lipases: Their role in biotechnology and cellular physiology. Prog. Lipid Res. 2015, 57, 40-54. [CrossRef] [PubMed]

61. Kumari, A.; Gupta, R. Phenylalanine to leucine point mutation in oxyanion hole improved catalytic efficiency of Lip12 from Yarrowia lipolytica. Enzym. Microb. Technol. 2013, 53, 386-390. [CrossRef]

62. Pleiss, J.; Fischer, M.; Peiker, M.; Thiele, C.; Schmid, R.D. Lipase engineering database: Understanding and exploiting sequence-structure-function relationships. J. Mol. Catal. B Enzym. 2000, 10, 491-508. [CrossRef]

63. Lenfant, N.; Hotelier, T.; Velluet, E.; Bourne, Y.; Marchot, P.; Chatonnet, A. ESTHER, the database of the $\alpha / \beta$-hydrolase fold superfamily of proteins: Tools to explore diversity of functions. Nucleic Acids Res. 2012, 41, D423-D429. [CrossRef]

64. Korman, T.P.; Bowie, J.U. Crystal structure of Proteus mirabilis lipase, a novel lipase from the Proteus/psychrophilic subfamily of lipase family I.1. PLoS ONE 2012, 7. [CrossRef]

65. Bassegoda, A.; Pastor, F.I.J.; Diaz, P. Rhodococcus sp. strain CR-53 lipr, the first member of a new bacterial lipase family (Family X) displaying an unusual Y-type oxyanion hole, similar to the Candida antarctica lipase clan. Appl. Environ. Microbiol. 2012, 78, 1724-1732. [CrossRef] [PubMed]

66. Cygler, M.; Schrag, J.D.; Bouthillier, F.; Grochulski, P.; Kazlauskas, R.J.; Serreq, A.N.; Gupta, A.K.; Rubin, B. A structural basis for the chiral preferences of lipases. J. Am. Chem. Soc. 1994, 116, 3180-3186. [CrossRef]

67. Carrasco-López, C.; Godoy, C.; de las Rivas, B.; Fernández-Lorente, G.; Palomo, J.M.; Guisán, J.M.; Fernández-Lafuente, R.; Martínez-Ripoll, M.; Hermoso, J.A. Activation of bacterial thermo alkalophilic lipases is spurred by dramatic structural rearrangements. J. Biol. Chem. 2009, 284, 4365-4372. [CrossRef] [PubMed]

68. Krieger, E.; Koraimann, G.; Vriend, G. Increasing the precision of comparative models with YASARA NOVA-A self-parameterizing force field. Proteins Struct. Funct. Bioinform. 2002, 47, 393-402. [CrossRef]

69. Rose, A.S.; Bradley, A.R.; Valasatava, Y.; Duarte, J.M.; Prlic, A.; Rose, P.W. NGL viewer: Web-based molecular graphics for large complexes. Bioinformatics 2018, 34, 3755-3758. [CrossRef]

70. Holmquist, M. Insights into the molecular basis for fatty acyl specificities of lipases from Geotrichum candidum and Candida rugosa. Chem. Phys. Lipids 1998, 93, 57-65. [CrossRef]

71. Widmann, M.; Juhl, P.B.; Pleiss, J. Structural classification by the Lipase Engineering Database: A case study of Candida antarctica lipase A. BMC Genom. 2010, 11, 1-8. [CrossRef] 
72. Chen, H.; Wu, J.; Yang, L.; Xu, G. Characterization and structure basis of Pseudomonas alcaligenes lipase's enantiopreference towards D,L-menthyl propionate. J. Mol. Catal. B Enzym. 2014, 102, 81-87. [CrossRef]

73. Panizza, P.; Cesarini, S.; Diaz, P.; Rodríguez Giordano, S. Saturation mutagenesis in selected amino acids to shift Pseudomonas sp. acidic lipase Lip I.3 substrate specificity and activity. Chem. Commun. 2015, 51, 1330-1333. [CrossRef]

74. Ghosh, D.; Wawrzak, Z.; Pletnev, V.Z.; Li, N.; Kaiser, R.; Pangborn, W.; Jörnvall, H.; Erman, M.; Duax, W.L. Structure of uncomplexed and linoleate-bound Candida cylindracea cholesterol esterase. Structure 1995, 3, 279-288. [CrossRef]

75. Quaglia, D.; Alejaldre, L.; Ouadhi, S.; Rousseau, O.; Pelletier, J.N. Holistic engineering of Cal-A lipase chain-length selectivity identifies triglyceride binding hot-spot. PLoS ONE 2019, 14, 1-17. [CrossRef]

76. Turner, J.M.; Larsen, N.A.; Basran, A.; Barbas, C.F.; Bruce, N.C.; Wilson, I.A.; Lerner, R.A. Biochemical characterization and structural analysis of a highly proficient cocaine esterase. Biochemistry 2002, 41, 12297-12307. [CrossRef] [PubMed]

77. Jaeger, K.-E.; Reetz, M.T. Microbial lipases form versatile tools for biotechnology. Trends Biotechnol. 1998, 16, 396-403. [CrossRef]

78. Heikinheimo, P.; Goldman, A.; Jeffries, C.; Ollis, D.L. Of barn owls and bankers: A lush variety of $\alpha / \beta$ hydrolases. Structure 1999, 7, R141-R146. [CrossRef]

79. Gupta, R.; Gupta, N.; Rathi, P. Bacterial lipases: An overview of production, purification and biochemical properties. Appl. Microbiol. Biotechnol. 2004, 64, 763-781. [CrossRef] [PubMed]

80. Nardini, M.; Dijkstra, B.W. $\alpha / \beta$ hydrolase fold enzymes: The family keeps growing. Curr. Opin. Struct. Biol. 1999, 9, 732-737. [CrossRef]

81. Petersen, M.T.N.; Fojan, P.; Petersen, S.B. How do lipases and esterases work: The electrostatic contribution. J. Biotechnol. 2001, 85, 115-147. [CrossRef]

82. Nardini, M.; Lang, D.A.; Liebeton, K.; Jaeger, K.E.; Dijkstra, B.W. Crystal structure of Pseudomonas aeruginosa lipase in the open conformation. The prototype for family I.1 of bacterial lipases. J. Biol. Chem. 2000, 275, 31219-31225. [CrossRef]

83. Uppenberg, J.; Ohmer, N.; Norin, M.; Hult, K.; Kleywegt, G.J.; Patkar, S.; Waagen, V.; Anthonsen, T.; Jones, T.A. Crystallographic and molecular-modeling studies of lipase B from Candida antarctica reveal a stereospecificity pocket for secondary alcohols. Biochemistry 1995, 34, 16838-16851. [CrossRef]

84. Derewenda, U.; Brzozowski, A.; Lawson, D.M.; Derewenda, Z.S. Catalysis at the interface: The anatomy of a conformational change in. Biochemistry 1992, 31, 1532-1541. [CrossRef] [PubMed]

85. Egloff, M.-P.; Marguet, F.; Buono, G.; Verger, R.; Cambillau, C.; Van Tilbeurgh, H. A resolution structure of the pancreatic lipase-colipase complex. Biochemistry 1995, 34, 2751-2762. [CrossRef] [PubMed]

86. Fersht, A. Structure and Mechanism in Protein Science: A Guide to Enzyme Catalysis and Protein Folding; Macmillan: New York, NY, USA, 1999; ISBN 0716732688.

87. Pauling, L. Chemical achievement and hope for the future. Am. Sci. 1948, 36, 51. [PubMed]

88. Warshel, A. Energetics of enzyme catalysis. Proc. Natl. Acad. Sci. USA 1978, 75, 5250-5254. [CrossRef] [PubMed]

89. Xu, H.; Lan, D.; Yang, B.; Wang, Y. Biochemical Properties and Structure Analysis of a DAG-Like Lipase from Malassezia globosa. Int. J. Mol. Sci. 2015, 16, 4865-4879. [CrossRef] [PubMed]

90. Barriuso, J.; Vaquero, M.E.; Prieto, A.; Martínez, M.J. Structural traits and catalytic versatility of the lipases from the Candida rugosa-like family: A review. Biotechnol. Adv. 2016, 34, 874-885. [CrossRef]

91. Hedfors, C.; Hult, K.; Martinelle, M. Lipase chemoselectivity towards alcohol and thiol acyl acceptors in a transacylation reaction. J. Mol. Catal. B Enzym. 2010, 66, 120-123. [CrossRef]

92. Taniguchi, I.; Kuhlman, W.A.; Mayes, A.M.; Griffith, L.G. Functional modification of biodegradable polyesters through a chemoselective approach: Application to biomaterial surfaces. Polym. Int. 2006, 55, 1385-1397. [CrossRef]

93. Uyama, H.; Kobayashi, S.; Morita, M.; Habaue, S.; Okamoto, Y. Chemoselective ring-opening polymerization of a lactone having exo-methylene group with lipase catalysis. Macromolecules 2001, 34, 6554-6556. [CrossRef]

94. Veld, M.A.J.; Palmans, A.R.A.; Meijer, E.W. Selective polymerization of functional monomers with Novozym 435. J. Polym. Sci. Part A Polym. Chem. 2007, 45, 5968-5978. [CrossRef] 
95. Van Der Meulen, I.; De Geus, M.; Antheunis, H.; Deumens, R.; Joosten, E.A.J.; Koning, C.E.; Heise, A. Polymers from functional macrolactones as potential biomaterials: Enzymatic ring opening polymerization, biodegradation, and biocompatibility. Biomacromolecules 2008, 9, 3404-3410. [CrossRef]

96. Polloni, A.E.; Chiaradia, V. Polyesters from Macrolactones Using Commercial Lipase NS 88011 and Novozym 435 as Biocatalysts. Appl. Biochem. Biotechnol. 2017, 184, 659-672. [CrossRef] [PubMed]

97. Zhu, N.; Zhang, Z.-L.; He, W.; Geng, X.-C.; Fang, Z.; Li, X.; Li, Z.-J.; Guo, K. Highly chemoselective lipase from Candida sp. 99-125 catalyzed ring-opening polymerization for direct synthesis of thiol-terminated poly ( $\varepsilon$-caprolactone). Chin. Chem. Lett. 2015, 26, 361-364. [CrossRef]

98. Li, Y.M.; Chang, X.P.; Cheng, Y.J.; Chen, S.; He, F.; Zhuo, R.X. Mercaptan acids modified amphiphilic copolymers for efficient loading and release of doxorubicin. Colloids Surf. B Biointerfaces 2017, 153, 220-228. [CrossRef] [PubMed]

99. Borza, P.; Peter, F.; Paul, C. Improved enantioselectivity of Candida antarctica A lipase through sol-gel entrapment. Chem.Bull "POLITEHNICA" Univ. (Timisoara). 2015, 60, 49-54.

100. Ribeiro, B.D.; de Castro, A.M.; Coelho, M.A.Z.; Freire, D.M.G. Production and use of lipases in bioenergy: A review from the feedstocks to biodiesel production. Enzym. Res. 2011, 2011, 1-16. [CrossRef]

101. Wuensch, C.; Glueck, S.M.; Gross, J.; Koszelewski, D.; Schober, M.; Faber, K. Regioselective enzymatic carboxylation of phenols and hydroxystyrene derivatives. Org. Lett. 2012, 14, 1974-1977. [CrossRef]

102. Oláh, J.; Mulholland, A.J.; Harvey, J.N. Understanding the determinants of selectivity in drug metabolism through modeling of dextromethorphan oxidation by cytochrome P450. Proc. Natl. Acad. Sci. USA 2011, 108, 6050-6055. [CrossRef]

103. Chaker, L.; Yongye, A.B.; Nefzi, A.; Martínez-Mayorga, K. Prediction of the experimental regioselectivity of C60 fullerene bis-adducts. J. Phys. Org. Chem. 2012, 25, 894-901. [CrossRef]

104. Lonsdale, R.; Houghton, K.T.; Zurek, J.; Bathelt, C.M.; Foloppe, N.; De Groot, M.J.; Harvey, J.N.; Mulholland, A.J. Quantum mechanics/molecular mechanics modeling of regioselectivity of drug metabolism in cytochrome P450 2C9. J. Am. Chem. Soc. 2013, 135, 8001-8015. [CrossRef]

105. Johnston, J.B.; Singh, A.A.; Clary, A.A.; Chen, C.K.; Hayes, P.Y.; Chow, S.; De Voss, J.J.; Ortiz De Montellano, P.R. Substrate analog studies of the $\omega$-regiospecificity of Mycobacterium tuberculosis cholesterol metabolizing cytochrome P450 enzymes CYP124A1, CYP125A1 and CYP142A1. Bioorg. Med. Chem. 2012, 20, 4064-4081. [CrossRef]

106. Bustamante, E.; Pedersen, P.L. High aerobic glycolysis of rat hepatoma cells in culture: Role of mitochondrial hexokinase. Proc. Natl. Acad. Sci. USA 1977, 74, 3735-3739. [CrossRef] [PubMed]

107. Kumar, V.; Jahan, F.; Mahajan, R.V.; Saxena, R.K. Efficient regioselective acylation of quercetin using Rhizopus oryzae lipase and its potential as antioxidant. Bioresour. Technol. 2016, 218, 1246-1248. [CrossRef]

108. Rivero, C.W.; Palomo, J.M. Covalent immobilization of Candida rugosa lipase at Alkaline $\mathrm{pH}$ and their application in the regioselective deprotection of Per-O-acetylated thymidine. Catalysts 2016, 6, 115. [CrossRef]

109. Paques, F.W.; Macedo, G.A. Plant lipases from latex: Properties and industrial applications [lipases De Látex Vegetais: Propriedades E Aplicações Industriais]. Quim. Nova 2006, 29, 93-99. [CrossRef]

110. Huh, J.W.; Yokoigawa, K.; Esaki, N.; Soda, K. Total conversion of racemic pipecolic acid into the L-enantiomer by a combination of enantiospecific oxidation with D-amino acid oxidase and reduction with sodium borohydride. Biosci. Biotechnol. Biochem. 1992, 56, 2081-2082.

111. Schulz, T.; Schmid, R.D.; Pleiss, J. Structural basis of stereoselectivity in Candida rugosa lipase-catalyzed hydrolysis of secondary alcohols. Mol. Model. Annu. 2001, 7, 265-270. [CrossRef]

112. Kobayashi, R.; Hirano, N.; Kanaya, S.; Saito, I.; Haruki, M. Enhancement of the enzymatic activity of Escherichia coli acetyl esterase by random mutagenesis. J. Mol. Catal. B Enzym. 2010, 67, 155-161. [CrossRef]

113. Chen, H.; Meng, X.; Xu, X.; Liu, W.; Li, S.; Chen, H. The molecular basis for lipase stereoselectivity. Appl. Microbiol. Biotechnol. 2018, 102, 3487-3495. [CrossRef] [PubMed]

114. Muralidhar, R.V.; Chirumamilla, R.R.; Marchant, R.; Ramachandran, V.N.; Ward, O.P.; Nigam, P. Understanding lipase stereoselectivity. World J. Microbiol. Biotechnol. 2002, 18, 81-97. [CrossRef]

115. Li, J.; Yue, L.; Li, C.; Pan, Y.; Yang, L. Enantioselectivity and catalysis improvements of Pseudomonas cepacia lipase with Tyr and Asp modification. Catal. Sci. Technol. 2015, 5, 2681-2687. [CrossRef]

116. Kapoor, M.; Gupta, M.N. Lipase promiscuity and its biochemical applications. Process Biochem. 2012, 47, 555-569. [CrossRef] 
117. Soumanou, M.M.; Pérignon, M.; Villeneuve, P. Lipase-catalyzed interesterification reactions for human milk fat substitutes production: A review. Eur. J. Lipid Sci. Technol. 2013, 115, 270-285. [CrossRef]

118. Horchani, H.; Aissa, I.; Ouertani, S.; Zarai, Z.; Gargouri, Y.; Sayari, A. Staphylococcal lipases: Biotechnological applications. J. Mol. Catal. B Enzym. 2012, 76, 125-132. [CrossRef]

119. Laguerre, M.; Nlandu Mputu, M.; Brïys, B.; Lopez, M.; Villeneuve, P.; Dubreucq, E. Regioselectivity and fatty acid specificity of crude lipase extracts from Pseudozyma tsukubaensis, Geotrichum candidum, and Candida rugosa. Eur. J. Lipid Sci. Technol. 2017, 119, 1600302. [CrossRef]

120. Ota, Y.; Sawamoto, T.; Hasuo, M. Tributyrin specifically induces a lipase with a preference for the sn-2 position of triglyceride in Geotrichum sp. FO401B. Biosci. Biotechnol. Biochem. 2000, 64, 2497-2499. [CrossRef]

121. Sugihara, A.; Hata, S.; Shimada, Y.; Goto, K.; Tsunasawa, S.; Tominaga, Y. Characterization of Geotrichum candidum lipase III with some preference for the inside ester bond of triglyceride. Appl. Microbiol. Biotechnol. 1993, 40, 279-283. [CrossRef] [PubMed]

122. Sarkar, P.; Yamasaki, S.; Basak, S.; Bera, A.; Bag, P.K. Purification and characterization of a new alkali-thermostable lipase from Staphylococcus aureus isolated from Arachis hypogaea rhizosphere. Process Biochem. 2012, 47, 858-866. [CrossRef]

123. Yan, Q.; Duan, X.; Liu, Y.; Jiang, Z.; Yang, S. Expression and characterization of a novel 1,3-regioselective cold-adapted lipase from Rhizomucor endophyticus suitable for biodiesel synthesis. Biotechnol. Biofuels 2016, 9 , 1-13. [CrossRef] [PubMed]

124. Ishii, M. Thermally Stable and Positionally Non-Specific Lipase Isolated from Candida. US patent 5273898, 28 December 1992.

125. Schmid, R.D.; Verger, R. Lipases: Interfacial enzymes with attractive applications. Angew. Chem. Int. Ed. 1998, 37, 1608-1633. [CrossRef]

126. Tong, X.; Busk, P.K.; Lange, L. Characterization of a new sn-1,3-regioselective triacylglycerol lipase from Malbranchea Cinnamomea. Biotechnol. Appl. Biochem. 2016, 63, 471-478. [CrossRef] [PubMed]

127. Fernandez-Lafuente, R. Lipase from Thermomyces lanuginosus: Uses and prospects as an industrial biocatalyst. J. Mol. Catal. B Enzym. 2010, 62, 197-212. [CrossRef]

128. Brígida, A.I.S.; Amaral, P.F.F.; Coelho, M.A.Z.; Gonçalves, L.R.B. Lipase from Yarrowia lipolytica: Production, characterization and application as an industrial biocatalyst. J. Mol. Catal. B Enzym. 2014, 101, 148-158. [CrossRef]

129. Stöcklein, W.; Sztajer, H.; Menge, U.; Schmid, R.D. Purification and properties of a lipase from Penicillium expansum. Biochim. Biophys. Acta 1993, 1168, 181-189. [CrossRef]

130. Lanser, A.C.; Manthey, L.K.; Hou, C.T. Regioselectivity of New Bacterial Lipases Determined by Hydrolysis of Triolein. Curr. Microbiol 2002, 44, 336-340. [CrossRef] [PubMed]

131. Sangeetha, R.; Arulpandi, I.; Geetha, A. Bacterial lipases as potential industrial biocatalysts: An overview. Res. J. Microbiol. 2011, 6, 1-24. [CrossRef]

132. Royter, M.; Schmidt, M.; Elend, C.; Höbenreich, H.; Schäfer, T.; Bornscheuer, U.T.; Antranikian, G. Thermostable lipases from the extreme thermophilic anaerobic bacteria Thermoanaerobacter thermohydrosulfuricus SOL1 and Caldanaerobacter subterraneus subsp. tengcongensis. Extremophiles 2009, 13, 769-783. [CrossRef]

133. Ahmed, E.H.; Raghavendra, T.; Madamwar, D. A thermostable alkaline lipase from a local isolate Bacillus subtilis EH 37: Characterization, partial purification, and application in organic synthesis. Appl. Biochem. Biotechnol. 2010, 160, 2102-2113. [CrossRef]

134. Joseph, B.; Ramteke, P.W.; Thomas, G. Cold active microbial lipases: Some hot issues and recent developments. Biotechnol. Adv. 2008, 26, 457-470. [CrossRef]

135. Cai, Y.; Wang, L.; Liao, X.; Ding, Y.; Sun, J. Purification and partial characterization of two new cold-adapted lipases from mesophilic Geotrichum sp. SYBC WU-3. Process Biochem. 2009, 44, 786-790. [CrossRef]

136. Champagne, E.; Strandman, S.; Zhu, X. Recent developments and optimization of lipase-catalyzed lactone formation and ring-opening polymerization. Macromol. Rapid Commun. 2016, 37, 1986-2004. [CrossRef] [PubMed]

137. Castillo, E.; Casas-Godoy, L.; Sandoval, G. Medium-engineering: A useful tool for modulating lipase activity and selectivity. Biocatalysis 2016, 1, 178-188. [CrossRef] 
138. Priego, J.; Ortíz-Nava, C.; Carrillo-Morales, M.; López-Munguía, A.; Escalante, J.; Castillo, E. Solvent engineering: An effective tool to direct chemoselectivity in a lipase-catalyzed Michael addition. Tetrahedron 2009, 65, 536-539. [CrossRef]

139. Coleman, M.H.; Macrae, A.R. Rearrangement of fatty acid esters in fat reaction reactants. Ger. Pat. 1977, $2,608$.

140. Masayama, A.; Takahashi, T.; Tsukada, K.; Nishikawa, S.; Takahashi, R.; Adachi, M.; Koga, K.; Suzuki, A.; Yamane, T.; Nakano, H.; et al. Streptomyces phospholipase D mutants with altered substrate specificity capable of phosphatidylinositol synthesis. ChemBioChem 2008, 9, 974-981. [CrossRef] [PubMed]

141. Oroz-guinea, I.; Zorn, K.; Bornscheuer, U.T. Enhancement of lipase CAL-A selectivity by protein engineering for the hydrolysis of erucic acid from crambe oil. Eur. J. Lipid Sci. Tech. 2020, 1900115, 1-6. [CrossRef]

142. Brundiek, H.; Padhi, S.K.; Kourist, R.; Evitt, A.; Bornscheuer, U.T. Altering the scissile fatty acid binding site of Candida antarctica lipase A by protein engineering for the selective hydrolysis of medium chain fatty acids. Eur. J. Lipid Sci. Technol. 2012, 114, 1148-1153. [CrossRef]

143. Sharma, S.; Kanwar, S.S. Organic solvent tolerant lipases and applications. Sci. World J. 2014, 2014. [CrossRef]

144. Patel, V.; Gajera, H.; Gupta, A.; Manocha, L.; Madamwar, D. Synthesis of ethyl caprylate in organic media using Candida rugosa lipase immobilized on exfoliated graphene oxide: Process parameters and reusability studies. Biochem. Eng. J. 2015, 95, 62-70. [CrossRef]

145. Zorn, K.; Oroz-guinea, I.; Brundiek, H.; Do, M.; Bornscheuer, U.T. Alteration of chain length selectivity of Candida antarctica lipase a by semi-rational design for the enrichment of erucic and gondoic fatty acids. Adv. Synth. Catal. 2018, 360, 4115-4131. [CrossRef]

146. Engström, K.; Nyhlén, J.; Sandström, A.G.; Bäckvall, J.E. Directed evolution of an enantioselective lipase with broad substrate scope for hydrolysis of $\alpha$-substituted esters. J. Am. Chem. Soc. 2010, 132, 7038-7042. [CrossRef] [PubMed]

147. Ono, M.; Suzuki, K.; Tanikawa, S.; Akita, H. First synthesis of (+)- and (-)-elvirol based on an enzymatic function. Tetrahedron Asymmetry 2001, 12, 2597-2604. [CrossRef]

148. Svendsen, A.; Gregory, P.C.; Borch, K. Lipases for Pharmaceutical Use. US patent 20090047266A1, 19 February 2009.

149. Grabner, G.F.; Zimmermann, R.; Schicho, R.; Taschler, U. Monoglyceride lipase as a drug target: At the crossroads of arachidonic acid metabolism and endocannabinoid signaling. Pharmacol. Therapeut. 2017, 175, 35-46. [CrossRef] [PubMed]

150. Pan, D.; Pham, C.T.N.; Weilbaecher, K.N.; Tomasson, M.H.; Wickline, S.A.; Lanza, G.M. Contact-facilitated drug delivery with Sn2 lipase labile prodrugs optimize targeted lipid nanoparticle drug delivery. Wiley Interdiscip. Rev. Nanomed. Nanobiotechnol. 2016, 8, 85-106. [CrossRef] [PubMed]

151. Loli,H.; Kumar Narwal, S.; Kumar Saun, N.; Gupta, R. Lipases in medicine: An overview. Mini-Rev. Med. Chem. 2015, 15, 1209-1216. [CrossRef] [PubMed]

152. Iso, M.; Chen, B.; Eguchi, M.; Kudo, T.; Shrestha, S. Production of biodiesel fuel from triglycerides and alcohol using immobilized lipase. J. Mol. Catal. B Enzym. 2001, 16, 53-58. [CrossRef]

153. Baron, A.M.; Barouh, N.; Barea, B.; Villeneuve, P.; Mitchell, D.A.; Krieger, N. Transesterification of castor oil in a solvent-free medium using the lipase from Burkholderia cepacia LTEB11 immobilized on a hydrophobic support. Fuel 2014, 117, 458-462. [CrossRef]

154. Amoah, J.; Ho, S.-H.; Hama, S.; Yoshida, A.; Nakanishi, A.; Hasunuma, T.; Ogino, C.; Kondo, A. Converting oils high in phospholipids to biodiesel using immobilized Aspergillus oryzae whole-cell biocatalysts expressing Fusarium heterosporum lipase. Biochem. Eng. J. 2016, 105, 10-15. [CrossRef]

155. Li, Y.; Du, W.; Liu, D. Efficient biodiesel production from phospholipids-containing oil: Synchronous catalysis with phospholipase and lipase. Biochem. Eng. J. 2015, 94, 45-49. [CrossRef]

156. Kanmani, P.; Aravind, J.; Kumaresan, K. An insight into microbial lipases and their environmental facet. Int. J. Environ. Sci. Technol. 2015, 12, 1147-1162. [CrossRef]

157. Choudhury, P.; Bhunia, B. Industrial application of lipase: A review. Biopharm. J. 2017, 1, 41-47.

158. Meng, Y.; Li, S.; Yuan, H.; Zou, D.; Liu, Y.; Zhu, B.; Li, X. Effect of lipase addition on hydrolysis and biomethane production of Chinese food waste. Bioresour. Technol. 2015, 179, 452-459. [CrossRef] [PubMed]

159. Saravanan, D.; Anusuya, C.A.; Divya, B.B.; Usha, M. Environmentally benign scouring of wool fibers using mesophile acidic lipase. Fibers Polym. 2014, 15, 1902-1907. [CrossRef]

160. Adulkar, T.V.; Rathod, V.K. Pre-treatment of high fat content dairy wastewater using different commercial lipases. Desalin. Water Treat. 2015, 53, 2450-2455. [CrossRef] 
161. Rodrigues, J.P.; Orrico, A.C.A.; Junior, O.; Previdelli, M.A.; de Seno, L.O.; de Araújo, L.C.; de Sunada, N.S. Adding oil and lipase on the anaerobic digestion of pig manure. Ciência Rural 2014, 44, 544-547. [CrossRef]

162. Bojsen, K.; Borch, K.; Budolfsen, G.; Fuglsang, K.C.; Glad, S.S.; Petri, A.; Shamkant, A.P.; Svendsen, A.; Vind, J. Lipolytic Enzyme Variants. US patent 7851176B2, 25 December 2007.

163. Müller, J.; Sowa, M.A.; Dörr, M.; Bornscheuer, U.T. The acyltransferase activity of lipase CAL-A allows efficient fatty acid esters formation from plant oil even in an aqueous environment. Eur. J. Lipid Sci. Technol. 2015, 117, 1903-1907. [CrossRef]

164. Chowdhury, A.; Mitra, D. A kinetic study on the Novozyme 435-catalyzed esterification of free fatty acids with octanol to produce octyl esters. Biotechnol. Prog. 2015, 31, 1494-1499. [CrossRef]

165. Chaplin, J.A.; Gardiner, N.S.; Mitra, R.K.; Parkinson, C.J.; Portwig, M.; Mboniswa, B.A.; Evans-Dickson, M.D.; Brady, D.; Marais, S.F.; Reddy, S. Process for Preparing (-) Menthol and Similar Compounds. WO2002036795A2, 11 November 2006.

166. Ganguly, S.; Nandi, S. Process optimization of lipase catalyzed synthesis of diesters in a packed bed reactor. Biochem. Eng. J. 2015, 102, 2-5. [CrossRef]

167. Kim, J.-H.; Bhatia, S.K.; Yoo, D.; Seo, H.M.; Yi, D.-H.; Kim, H.J.; Lee, J.H.; Choi, K.-Y.; Kim, K.J.; Lee, Y.K. Lipase-catalyzed production of 6-o-cinnamoyl-sorbitol from d-sorbitol and cinnamic acid esters. Appl. Biochem. Biotechnol. 2015, 176, 244-252. [CrossRef] [PubMed]

168. Choi, J.-M.; Han, S.-S.; Kim, H.-S. Industrial applications of enzyme biocatalysis: Current status and future aspects. Biotechnol. Adv. 2015, 33, 1443-1454. [CrossRef] [PubMed]

169. Singh, R.; Kumar, M.; Mittal, A.; Mehta, P.K. Microbial enzymes: Industrial progress in 21st century. 3 Biotech. 2016, 6. [CrossRef]

170. Coker, J.A. Extremophiles and biotechnology: Current uses and prospects. F1000Research 2016, 5, 1-7. [CrossRef]

171. Bommarius, A.; Bommarius-Riebel, B. Fundamentals of Biocatalysis; Wiley-Blackwell: New Jersey, NJ, USA, 2005; ISBN 978-3-527-30344-1.

172. Woolley, P. Lipases; their structure, biochemistry and application. Seq. Anal. Lipases Esterases Relat. Proteins 1994, 22, 27-28.

173. Bhat, E.A.; Abdalla, M.; Rather, I.A. Key factors for successful protein purification and crystallization. Glob. J. Biotechnol. Biomater. Sci. 2018, 4, 1-7. [CrossRef]

174. Ortiz, C.; Ferreira, M.L.; Barbosa, O.; Dos Santos, J.C.S.; Rodrigues, R.C.; Berenguer-Murcia, Á.; Briand, L.E.; Fernandez-Lafuente, R. Novozym 435: The "perfect" lipase immobilized biocatalyst? Catal. Sci. Technol. 2019, 9, 2380-2420. [CrossRef]

175. Kazlauskas, R.J.; Bornscheuer, U.T. Finding better protein engineering strategies. Nat. Chem. Biol. 2009, 5, 526-529. [CrossRef]

176. Sissi, C.; Palumbo, M. Effects of magnesium and related divalent metal ions in topoisomerase structure and function. Nucleic Acids Res. 2009, 37, 702-711. [CrossRef]

177. Eckert, K.A.; Kunkel, T.A. DNA polymerase fidelity and the polymerase chain reaction. Genome Res. 1991, 1, 17-24. [CrossRef]

178. Stemmer, WP DNA shuffling by random fragmentation and reassembly: In vitro recombination for molecular evolution. Proc. Natl. Acad. Sci. USA 1994, 91, 10747-10751. [CrossRef] [PubMed]

179. Moore, J.C.; Arnold, F.H. Directed evolution of a para-nitrobenzyl esterase for aqueous-organic solvents. Nat. Biotechnol. 1996, 14, 458-467. [CrossRef] [PubMed]

180. Goddard, J.-P.; Reymond, J.-L. Enzyme assays for high-throughput screening. Curr. Opin. Biotechnol. 2004, 15, 314-322. [CrossRef] [PubMed]

181. Bommarius, A.S. Biocatalysis: A status report. Annu. Rev. Chem. Biomol. Eng. 2015, 6, 319-345. [CrossRef]

182. Sun, Z.; Wikmark, Y.; Bäckvall, J.E.; Reetz, M.T. New concepts for increasing the efficiency in directed evolution of stereoselective enzymes. Chem. A Eur. J. 2016, 22, 5046-5054. [CrossRef]

183. Pavelka, A.; Chovancova, E.; Damborsky, J. HotSpot Wizard: A web server for identification of hot spots in protein engineering. Nucleic Acids Res. 2009, 37, 376-383. [CrossRef]

184. Seelig, B.; Szostak, J.W. Selection and evolution of enzymes from a partially randomized non-catalytic scaffold. Nature 2007, 448, 828-831. [CrossRef]

185. Antikainen, N.M.; Martin, S.F. Altering protein specificity: Techniques and applications. Bioorgan. Med. Chem. 2005, 13, 2701-2716. [CrossRef] [PubMed] 
186. Reetz, M.T.; Carballeira, J.D.; Vogel, A. Iterative saturation mutagenesis on the basis of B factors as a strategy for increasing protein thermostability. Angew. Chem. Int. Ed. 2006, 45, 7745-7751. [CrossRef] [PubMed]

187. Svedendahl, M.; Jovanović, B.; Fransson, L.; Berglund, P. Suppressed native hydrolytic activity of a lipase to reveal promiscuous Michael addition activity in water. ChemCatChem 2009, 1, 252-258. [CrossRef]

188. Li, G.; Fang, X.; Su, F.; Chen, Y.; Xu, L.; Yan, Y. Enhancing the thermostability of Rhizomucor miehei lipase with a limited screening library by rational-design point mutations and disulfide bonds. Appl. Environ. Microbiol. 2018, 84. [CrossRef] [PubMed]

189. Park, H.J.; Joo, J.C.; Park, K.; Yoo, Y.J. Stabilization of Candida antarctica lipase B in hydrophilic organic solvent by rational design of hydrogen bond. Biotechnol. Bioprocess Eng. 2012, 17, 722-728. [CrossRef]

190. Le, Q.A.T.; Joo, J.C.; Yoo, Y.J.; Kim, Y.H. Development of thermostable Candida antarctica lipase B through novel in silico design of disulfide bridge. Biotechnol. Bioeng. 2012, 109, 867-876. [CrossRef] [PubMed]

191. Sebestova, E.; Bendl, J.; Brezovsky, J.; Damborsky, J. Computational tools for designing smart libraries. In Directed Evolution Library Creation; Springer: New York, NY, USA, 2014; Volume 1179, pp. 291-314. ISBN 978-1-4939-1052-6.

192. Smith, M. In vitro mutagenesis. Annu. Rev. Genet. 1985, 19, 423-462. [CrossRef]

193. Sharma, S.V.; Hooda, S. An analysis upon various strategies for redesign and direct evolution of enzyme engineering. Adv. Sci. Technol. 2017, 13, 144-150.

194. Bornscheuer, U.T.; Huisman, G.W.; Kazlauskas, R.J.; Lutz, S.; Moore, J.C.; Robins, K. Engineering the third wave of biocatalysis. Nature 2012, 485, 185-194. [CrossRef]

195. Geddie, M.L.; Matsumura, I. Rapid evolution of $\beta$-glucuronidase specificity by saturation mutagenesis of an active site loop. J. Biol. Chem. 2004, 279, 26462-26468. [CrossRef]

196. Reetz, M.T.; Carballeira, J.D. Iterative saturation mutagenesis (ISM) for rapid directed evolution of functional enzymes. Nat. Protoc. 2007, 2, 891. [CrossRef]

197. Reetz, M.T. Laboratory evolution of stereoselective enzymes: A prolific source of catalysts for asymmetric reactions. Angew. Chem. Int. Ed. 2011, 50, 138-174. [CrossRef] [PubMed]

198. Reetz, M.T.; Carballeira, J.D.; Peyralans, J.; Höbenreich, H.; Maichele, A.; Vogel, A. Expanding the substrate scope of enzymes: Combining mutations obtained by CASTing. Chem. Eur. J. 2006, 12, 6031-6038. [CrossRef] [PubMed]

199. DeSantis, G.; Wong, K.; Farwell, B.; Chatman, K.; Zhu, Z.; Tomlinson, G.; Huang, H.; Tan, X.; Bibbs, L.; Chen, $\mathrm{P}$. Creation of a productive, highly enantioselective nitrilase through gene site saturation mutagenesis (GSSM). J. Am. Chem. Soc. 2003, 125, 11476-11477. [CrossRef] [PubMed]

200. Dalby, P.A. Engineering enzymes for biocatalysis. Recent Pat. Biotechnol. 2007, 1, 1-9. [CrossRef] [PubMed]

201. Fischer, M.; Thai, Q.K.; Grieb, M.; Pleiss, J. DWARF-a data warehouse system for analyzing protein families. BMC Bioinform. 2006, 7, 495. [CrossRef]

202. Kourist, R.; Jochens, H.; Bartsch, S.; Kuipers, R.; Padhi, S.K.; Gall, M.; Böttcher, D.; Joosten, H.J.; Bornscheuer, U.T. The $\alpha / \beta$-hydrolase fold 3DM database (ABHDB) as a tool for protein engineering. ChemBioChem 2010, 11, 1635-1643. [CrossRef]

203. Fischer, M.; Pleiss, J. The Lipase Engineering Database: A navigation and analysis tool for protein families. Nucleic Acids Res. 2003, 31, 319-321. [CrossRef]

204. Berman, H.M.; Battistuz, T.; Bhat, T.N.; Bluhm, W.F.; Bourne, P.E.; Burkhardt, K.; Feng, Z.; Gilliland, G.L.; Iype, L.; Jain, S. The protein data bank. Acta Crystallogr. D Biol. Cryst. 2002, 58, 899-907. [CrossRef]

205. Benson, D.A.; Karsch-Mizrachi, I.; Lipman, D.J.; Ostell, J.; Rapp, B.A.; Wheeler, D.L. GenBank. Nucleic Acids Res. 2002, 30, 17-20. [CrossRef]

206. Radivojac, P.; Obradovic, Z.; Smith, D.K.; Zhu, G.; Vucetic, S.; Brown, C.J.; Lawson, J.D.; Dunker, A.K. Protein flexibility and intrinsic disorder. Protein Sci. 2004, 13, 71-80. [CrossRef]

207. Juhl, P.B.; Doderer, K.; Hollmann, F.; Thum, O.; Pleiss, J. Engineering of Candida antarctica lipase B for hydrolysis of bulky carboxylic acid esters. J. Biotechnol. 2010, 150, 474-480. [CrossRef] [PubMed]

208. Ruslan, R.; Rahman, R.N.Z.R.A.; Leow, T.C.; Ali, M.S.M.; Basri, M.; Salleh, A.B. Improvement of thermal stability via outer-loop ion pair interaction of mutated T1 lipase from Geobacillus zalihae strain T1. Int. J. Mol. Sci. 2012, 13, 943-960. [CrossRef] [PubMed]

209. Peng, X.-Q. Improved thermostability of lipase B from Candida antarctica by directed evolution and display on yeast surface. Appl. Biochem. Biotechnol. 2013, 169, 351-358. [CrossRef] [PubMed] 
210. Akbulut, N.; Öztürk, M.T.; Öztürk, S.İ.; Gümüşel, F. Improvement of the activity and thermostability of lipase producing local Bacillus pumilus isolates by directed evolution. J. Biotechnol. 2013, 164, 123-129. [CrossRef] [PubMed]

211. Subhedar, P.B.; Botelho, C.; Ribeiro, A.; Castro, R.; Pereira, M.A.; Gogate, P.R.; Cavaco-Paulo, A. Ultrasound intensification suppresses the need of methanol excess during the biodiesel production with Lipozyme TL-IM. Ultrason. Sonochem. 2015, 27, 530-535. [CrossRef]

212. Li, X.-J.; Zheng, R.-C.; Ma, H.-Y.; Zheng, Y.-G. Engineering of Thermomyces lanuginosus lipase Lip: Creation of novel biocatalyst for efficient biosynthesis of chiral intermediate of Pregabalin. Appl. Microbiol. Biotechnol. 2014, 98, 2473-2483. [CrossRef]

213. Wi, A.R.; Jeon, S.-J.; Kim, S.; Park, H.J.; Kim, D.; Han, S.J.; Yim, J.H.; Kim, H.-W. Characterization and a point mutational approach of a psychrophilic lipase from an arctic bacterium, Bacillus Pumilus. Biotechnol. Lett. 2014, 36, 1295-1302. [CrossRef]

214. Raftari, M.; Ghafourian, S.; Bakar, F.A. Metabolic engineering of Lactococcus lactis influence of the overproduction of lipase enzyme. J. Dairy Res. 2013, 80, 490-495. [CrossRef]

215. Zaugg, J.; Gumulya, Y.; Gillam, E.M.J.; Bodén, M. Computational tools for directed evolution: A comparison of prospective and retrospective strategies. Methods Mol. Biol. 2014, 1179, 315-333.

216. Nobili, A.; Tao, Y.; Pavlidis, I.V.; Van Den Bergh, T. Simultaneous use of in silico design and a correlated mutation network as a tool to efficiently guide enzyme engineering. ChemBioChem 2015, 16, 805-810. [CrossRef]

217. Damnjanović, J.; Kuroiwa, C.; Tanaka, H.; Ishida, K.; Nakano, H.; Iwasaki, Y. Directing positional specificity in enzymatic synthesis of bioactive 1-phosphatidylinositol by protein engineering of a phospholipase D. Biotechnol. Bioeng. 2016, 113, 62-71. [CrossRef]

218. Müller, J.; Sowa, M.A.; Fredrich, B.; Brundiek, H.; Bornscheuer, U.T. Enhancing the acyltransferase activity of Candida antarctica lipase A by rational design. ChemBioChem 2015, 16, 1791-1796. [CrossRef] [PubMed]

219. Jan, A.H.; Subileau, M.; Deyrieux, C.; Perrier, V.; Dubreucq, É. Elucidation of a key position for acyltransfer activity in Candida parapsilosis lipase/acyltransferase (CpLIP2) and in Pseudozyma antarctica lipase A (CAL-A) by rational design. Biochim. Biophys. Acta Proteins Proteom. 2016, 1864, 187-194. [CrossRef] [PubMed]

220. Schmitt, J.; Brocca, S.; Schmid, R.D.; Pleiss, J. Blocking the tunnel: Engineering of Candida rugosa lipase mutants with short chain length specificity. Protein Eng. 2002, 15, 595-601. [CrossRef] [PubMed]

221. Yu, X.-W.; Zhu, S.-S.; Xiao, R.; Xu, Y. Conversion of a Rhizopus chinensis lipase into an esterase by lid swapping. J. Lipid Res. 2014, 55, 1044-1051. [CrossRef]

222. Willems, N.; Lelimousin, M.; Skjold-Jørgensen, J.; Svendsen, A.; Sansom, M.S.P. The effect of mutations in the lid region of Thermomyces lanuginosus lipase on interactions with triglyceride surfaces: A multi-scale simulation study. Chem. Phys. Lipids 2018, 211, 4-15. [CrossRef]

223. Wikmark, Y.; Engelmarkcassimjee, K.; Lihammar, R.; Bäckvall, J.E. Removing the active-site flap in lipase A from Candida antarctica produces a functional enzyme without interfacial activation. ChemBioChem 2016, 17, 141-145. [CrossRef]

224. Tang, L.; Su, M.; Yan, J.; Xie, S.; Zhang, W. Lid hinge region of Penicillium expansum lipase affects enzyme activity and interfacial activation. Process Biochem. 2015, 50, 1218-1223. [CrossRef]

225. Sandström, A.G.; Engström, K.; Nyhlén, J.; Kasrayan, A.; Bäckvall, J.-E. Directed evolution of Candida antarctica lipase A using an episomaly replicating yeast plasmid. Protein Eng. Des. Sel. 2009, 22, 413-420. [CrossRef] [PubMed]

226. Lafaquière, V.; Barbe, S.; Puech-Guenot, S.; Guieysse, D.; Cortés, J.; Monsan, P.; Siméon, T.; André, I.; Remaud-Siméon, M. Control of lipase enantioselectivity by engineering the substrate binding site and access channel. ChemBioChem 2009, 10, 2760-2771. [CrossRef]

227. Yang, J.; Koga, Y.; Nakano, H.; Yamane, T. Modifying the chain-length selectivity of the lipase from Burkholderia cepacia KWI-56 through in vitro combinatorial mutagenesis in the substrate-binding site. Protein Eng. 2002, 15, 147-152. [CrossRef] [PubMed]

228. Park, H.S.; Nam, S.H.; Lee, J.K.; Yoon, C.N.; Mannervik, B.; Benkovic, S.J.; Kim, H.S. Design and evolution of new catalytic activity with an existing protein scaffold. Science 2006, 311, 535-538. [CrossRef] [PubMed]

229. Jochens, H.; Stiba, K.; Savile, C.; Fujii, R.; Yu, J.G.; Gerassenkov, T.; Kazlauskas, R.J.; Bornscheuer, U.T. Erratum: Converting an esterase into an epoxide hydrolase. Angew. Chem. Int. Ed. 2009, 48, 3532-3535. [CrossRef] [PubMed] 
230. Santarossa, G.; Lafranconi, P.G.; Alquati, C.; DeGioia, L.; Alberghina, L.; Fantucci, P.; Lotti, M. Mutations in the "lid" region affect chain length specificity and thermostability of a Pseudomonas fragi lipase. FEBS Lett. 2005, 579, 2383-2386. [CrossRef] [PubMed]

231. Damnjanović, J.; Nakano, H.; Iwasaki, Y.; Petersen, E. Acyl chain that matters: Introducing sn-2 acyl chain preference to a phospholipase D by protein engineering. Protein Eng. Des. Sel. 2019, 32, 1-11. [CrossRef]

232. Chang, R.; Chou, S.; Shaw, J. Synthesis of Fatty Acid Esters by Recombinant Staphylococcus epidermidis lipases in aqueous environment. J. Agric. Food Chem. 2001, 49, 2619-2622. [CrossRef]

233. Padhi, S.K.; Fujii, R.; Legatt, G.A.; Fossum, S.L.; Berchtold, R.; Kazlauskas, R.J. Article switching from an esterase to a hydroxynitrile lyase mechanism requires only two amino acid substitutions. Chem. Biol. 2010, 17, 863-871. [CrossRef] [PubMed]

234. Vallin, M.; Syrén, P.O.; Hult, K. Mutant lipase-catalyzed kinetic resolution of bulky phenyl alkyl sec-alcohols: A thermodynamic analysis of enantioselectivity. Chembiochem 2010, 11, 411-416. [CrossRef] [PubMed]

235. Liu, D.; Trodler, P.; Eiben, S.; Koschorreck, K.; Müller, M.; Pleiss, J.; Maurer, S.C.; Branneby, C.; Schmid, R.D.; Hauer, B. Rational design of Pseudozyma antarctica lipase B yielding a general esterification catalyst. Chembiochem 2010, 11, 789-795. [CrossRef]

236. Magnusson, A.O.; Rotticci-mulder, J.C.; Santagostino, A.; Hult, K. Creating space for large secondary alcohols by rational redesign of Candida antarctica Lipase B. Chembiochem 2005, 6, 1051-1056. [CrossRef] [PubMed]

237. Rotticci, D.; Rotticci-mulder, J.C.; Denman, S.; Norin, T.; Hult, K. Improved enantioselectivity of a lipase by rational protein engineering. Chembiochem 2001, 2, 766-770. [CrossRef]

238. Yu, X.W.; Tan, N.J.; Xiao, R.; Xu, Y. Engineering a disulfide bond in the lid hinge region of Rhizopus chinensis lipase: Increased thermostability and altered acyl chain length specificity. PLoS ONE 2012, 7. [CrossRef] [PubMed]

239. Fujii, R.; Nakagawa, Y.; Hiratake, J.; Sogabe, A.; Sakata, K. Directed evolution of Pseudomonas aeruginosa lipase for improved amide-hydrolyzing activity. Protein Eng. Des. Sel. 2005, 18, 93-101. [CrossRef]

240. Durmaz, E.; Kuyucak, S. Modifying the catalytic preference of tributyrin in Bacillus thermocatenulatus lipase through in-silico modeling of enzyme-substrate complex. Protein Eng. Des. Sel. 2013, 26, 325-333. [CrossRef] [PubMed]

241. Tang, W.; Lan, D.; Zhao, Z.; Li, S.; Li, X.; Wang, Y. A thermostable monoacylglycerol lipase from marine Geobacillus sp. 12AMOR1: Biochemical characterization and mutagenesis study. Int. J. Mol. Sci. 2019, 20, 780. [CrossRef] [PubMed]

242. Wikmark, Y.; Svedendahl Humble, M.; Bäckvall, J.E. Combinatorial library based engineering of Candida antarctica lipase A for enantioselective transacylation of sec-alcohols in organic solvent. Angew. Chem. Int. Ed. 2015, 54, 4284-4288. [CrossRef]

243. Liebeton, K.; Zonta, A.; Schimossek, K.; Nardini, M.; Lang, D.; Dijkstra, B.W.; Reetz, M.T.; Jaeger, K.E. Directed evolution of an enantioselective lipase. Chem. Biol. 2000, 7, 709-718. [CrossRef]

244. Reetz, M.T.; Bocola, M.; Carballeira, J.D.; Zha, D.; Vogel, A. Expanding the range of substrate acceptance of enzymes: Combinatorial active-site saturation test. Angew. Chem. Int. Ed. 2005, 44, 4192-4196. [CrossRef] [PubMed]

245. Joerger, R.D.; Haas, M.J. Alteration of chain length selectivity of a Rhizopus delemar lipase through site-directed mutagenesis. Lipids 1994, 29, 377. [CrossRef]

246. Klein, R.R.; King, G.; Moreau, R.A.; Haas, M.J. Altered acyl chain length specificity of Rhizopus delemar lipase through mutagenesis and molecular modeling. Lipids 1997, 32, 123. [CrossRef]

247. Dröge, M.J.; Boersma, Y.L.; Van Pouderoyen, G.; Vrenken, T.E.; Rüggeberg, C.J.; Reetz, M.T.; Dijkstra, B.W.; Quax, W.J. Directed evolution of Bacillus subtilis lipase A by use of enantiomeric phosphonate inhibitors: Crystal structures and phage display selection. ChemBioChem 2006, 7, 149-157. [CrossRef] [PubMed]

248. Reyes-Duarte, D.; Polaina, J.; López-Cortés, N.; Alcalde, M.; Plou, F.J.; Elborough, K.; Ballesteros, A.; Timmis, K.N.; Golyshin, P.N.; Ferrer, M. Conversion of a carboxylesterase into a triacylglycerol lipase by a random mutation. Angew. Chem. Int. Ed. 2005, 44, 7553-7557. [CrossRef] [PubMed]

(C) 2020 by the authors. Licensee MDPI, Basel, Switzerland. This article is an open access article distributed under the terms and conditions of the Creative Commons Attribution (CC BY) license (http://creativecommons.org/licenses/by/4.0/). 